Portland State University

PDXScholar

\title{
A Comprehensive Analysis of Teachers' Attributional Tendencies and Gender Bias Towards Failing Students with Learning Disabilities
}

Polly Chalette

Portland State University

Follow this and additional works at: https://pdxscholar.library.pdx.edu/open_access_etds

Part of the Sociology Commons

Let us know how access to this document benefits you.

Recommended Citation

Chalette, Polly, "A Comprehensive Analysis of Teachers' Attributional Tendencies and Gender Bias Towards Failing Students with Learning Disabilities" (1998). Dissertations and Theses. Paper 5834. https://doi.org/10.15760/etd.7705

This Thesis is brought to you for free and open access. It has been accepted for inclusion in Dissertations and Theses by an authorized administrator of PDXScholar. Please contact us if we can make this document more accessible: pdxscholar@pdx.edu. 


\section{THESIS APPROVAL}

The abstract and thesis of Polly Chalette for the Master of Science in

Sociology were presented May 8, 1998, and accepted by the thesis committee and the department.

COMMITTEE APPROVALS:
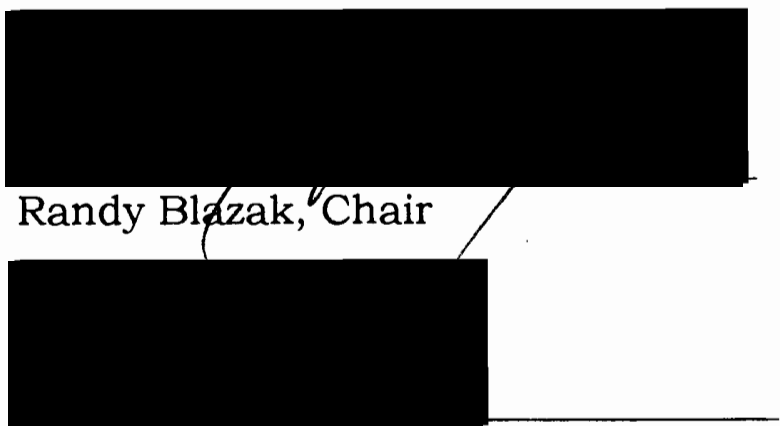

\section{Peter Collier}

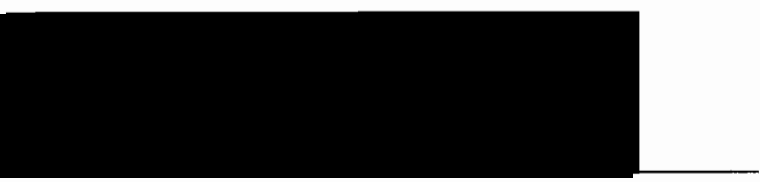

Steve Isaacson

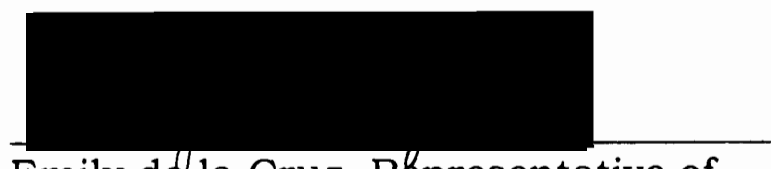

Emily de la Cruz, Representative of the Office of Graduate Studies

DEPARTMENTAL APPROVAL:

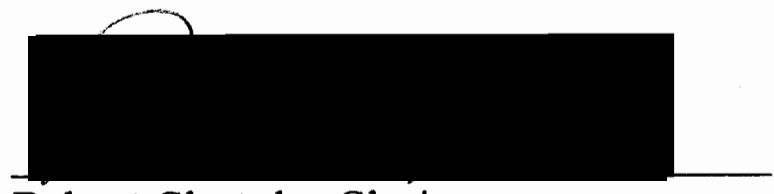

Robert Shotola, Chair Department of Sociology 


\section{ABSTRACT}

An abstract of the thesis of Polly Chalette for the Master of Science in Sociology presented May 8, 1998.

Title: A Comprehensive Analysis of Teachers' Attributional Tendencies and Gender Bias Towards Failing Students with Learning Disabilities

Student characteristics, such as sex, race, and socioeconomic status, have been found to influence teachers' perceptions of students and their patterns of interaction with them in the classroom. Behavior and achievement also has been shown to influence a teacher's perceptions. When teachers have been asked for evaluative comments and their expectations for future performance of a student, they have stated ability and effort as their explanations. This study will use the principles of Weiner's attribution theory dealing with success and failure in order to examine teachers' attributional tendencies towards a hypothetical student. 
This study intends to examine the degree to which a teacher's knowledge of the presence or absence of a learning disability, student's gender, and perceived ability and effort will influence (a) the level of reward or punishment given to a hypothetical student, (b) the amount of pity or anger the teacher feels, and (c) the expectations the teacher holds for the child's future failure.

Eighty subjects (52 females and 23 males) from Portland State University School of Education completed a survey asking them rate their responses to hypothetical male and female students with and without learning disabilities. An analysis of variance and a multiple regression were completed for each dependent variable. Mean responses were also calculated for each dependent variable crossed by the independent variables. It was found that whether or not the hypothetical student was male or female did not have significance upon the response the subjects gave. The variable that was found to have the most significance and explain the dependent variables the most was the amount of effort the hypothetical student was perceived as having. The results concerning effort are consistent with previous research showing that teachers' attributional tendencies are most influenced by the amount of effort a student is perceived as having. 
A COMPREHENSIVE ANALYSIS OF TEACHERS' ATTRIBUTIONAL

TENDENCIES AND GENDER BIAS TOWARDS

FAILING STUDENTS WITH LEARNING DISABILITIES

By

POLLY CHALETTE

A thesis submitted in partial fulfillment of the

Requirements for the degree of

MASTER OF SCIENCE

in

SOCIOLOGY

Portland State University

1998 


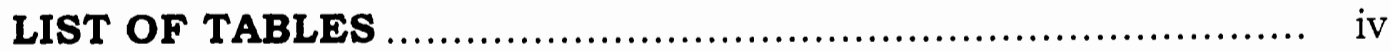

CHAPTER 1 ...................................................... 1

Introduction .......................................................... 1

Learning disabilities ............................................ 2

Gender differences............................................. 4

Attribution research .................................................. 14

Conclusion ..................................................... 29

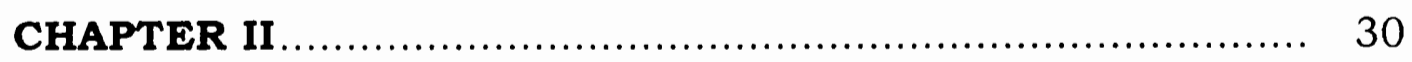

THEORETICAL PERSPECTIVES

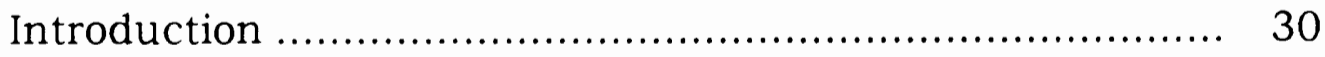

Attribution theory ............................................. 30

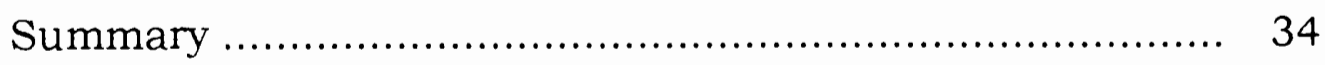

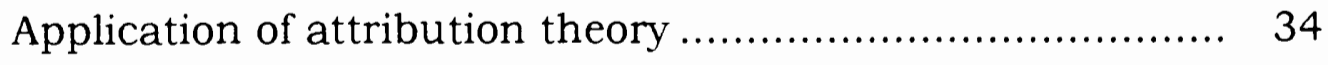

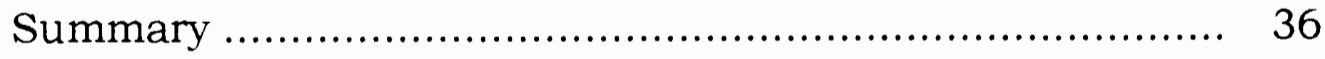

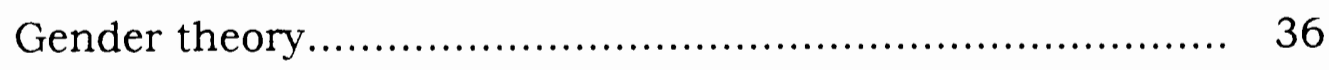

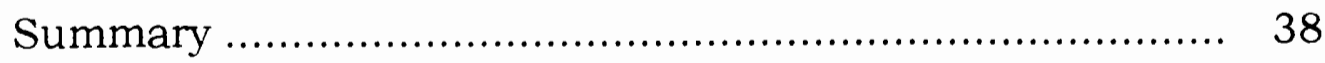


Hypotheses....................................................... 39

Conclusion ................................................. 40

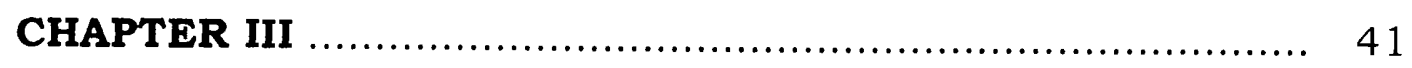

METHODOLOGY

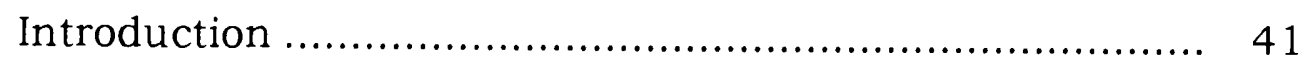

Subjects ........................................................ 41

Instrument ................................................. 42

Procedure ..................................................... 44

Independent variables....................................... 45

Dependent variables ........................................... 46

Conclusion ................................................. 47

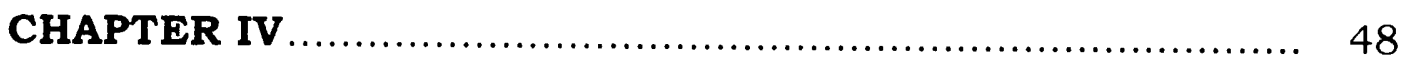

FINDINGS

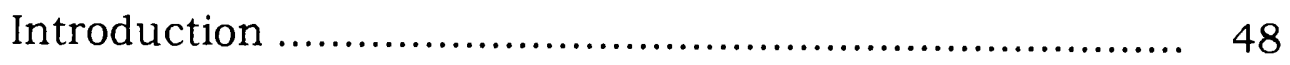

Demographic statistics ....................................... 48

Reward ........................................................ 49

Anger ........................................................... 54

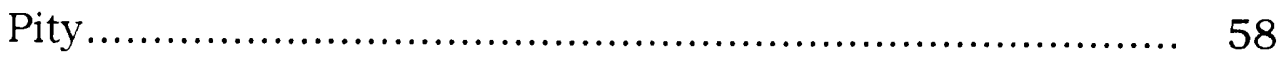


Expectations for future failure

62

Interactions between variables

66

Conclusion

68

CHAPTER V

69

DISCUSSION AND CONCLUSION

Introduction

69

Reward 69

Anger 73

Pity. 75

Expectations for future failure 77

Conclusion 80

Applicability to teachers. 85

Directions for future research 86

REFERENCES 88

APPENDIX A: SURVEY 93

APPENDIX B: CONSENT FORM 101 APPENDIX C: FACTORIAL ANALYSIS OF VARIANCE 102 


\section{LIST OF TABLES}

TABLE

PAGE

1 Mean teacher responses to reward question ................ 50

2 Oneway ANOVA with reward as dependent variable ...... 52

3 Regression with reward as dependent variable ............. 54

4 Mean teacher responses to anger question................. 55

5 Oneway ANOVA with anger as dependent variable ........ 57

6 Regression with anger as dependent variable .............. 57

7 Mean teacher responses to pity question................... 59

8 Oneway ANOVA with pity as dependent variable .......... 60

9 Regression with pity as dependent variable ................ 61

10 Mean responses to future failure question.................. 63

11 Oneway ANOVA with fail as dependent variable ........... 64

12 Regression with fail as dependent variable .................. 65 


\section{CHAPTER I}

\section{INTRODUCTION}

Teachers enter their classrooms with preconceived ideas about their students including ideas about how certain students are supposed to act, and how well the students are going to do in the class (Brophy \& Good, 1974). Student characteristics, such as sex, race, and socioeconomic status (SES), have been found to influence teachers' perceptions of students and their patterns of interaction with them in the classroom (Brophy \& Good, 1974). Other characteristics, such as behavior and achievement also influence teachers' perceptions (Brophy \& Good, 1974). When teachers have been asked for evaluative comments and their expectations for future performance of a student, they have stated ability and effort as their explanations (Clark, 1997). Attribution research has identified ability and effort as the principle causes of individual success or failure (Weiner, 1972, 1977, 1978).

Will teachers be consistent with their feedback to both boys and girls based on ability and effort? Or, will there be a tendency to view boys and girls differently? How will the knowledge of a student having a learning disability (LD) effect the teacher's attributional tendencies? This study intends to examine the degree to which a 
teacher's knowledge of the presence or absence of a learning disability, student's gender, and perceived ability and effort, will influence (a) the level of reward or punishment given to a hypothetical student, (b) the amount of pity or anger the teacher feels, and (c) the expectations the teacher holds for the child's future failure. The principles from attribution theory will be utilized to explain the teachers' attributional tendencies toward their failing students.

\section{LEARNING DISABILITIES}

The number of learning disabled students between the ages of 6 to 21 has tripled since the federal government started keeping data in 1976 to 1977 (Hallahan, Kauffman, \& Lloyd, 1996). According to the U.S. Department of Education (1994), "public schools have identified approximately 2.3 million students as learning disabled" (Hallahan, Kauffman, \& Lloyd, 1996; p. 47). This estimation is probably lower than what the actual number is because private schools are not included in the number. The fact that the number of students being diagnosed as learning disabled has increased is correct. The reason for the increasing prevalence is debatable. Some authorities (Hallahan, Kauffman, \& Lloyd, 1996) 
believe that there has been an increase in the misdiagnosis of learning disabilities, and this is reason for the increase. Others believe that there are valid reasons for the increase in diagnoses (Hallahan, Kauffman, \& Lloyd, 1996). One reason for the increase was because the field of learning disabilities was fairly new when the federal government started collecting data, so there might have been a period of adjustment for the professionals who diagnosed the students (Hallahan, Kauffman, \& Lloyd, 1996). Another explanation is that there have been social and cultural changes over the past 30 years that might have added to students developing learning disabilities (Hallahan, Kauffman, \& Lloyd, 1996). Whatever the reason for the increase in learning disabled students, the fact remains that these students are being found more and more in regular classrooms and the teachers have to deal with their learning deficits.

November 29, 1975, President Ford signed a piece of federal legislation called the Education for All Handicapped Children Act (PL 94-142). This act was very specific in its requirements.

It ensured the provision of a free, appropriate education to all children with disabilities; establishes evaluation and assessment policy; guarantees the right to due process of law; and establishes a process for financial support of educational services (Mercer, 1991: p. 18). 
This act also mandated a more precise definition of learning disabilities. There have been many different definitions of learning disabilities and there has been debate over what should be included in the definition. One of the widely used definitions comes from the United States Office of Education.

The term "specific learning disability" means a disorder in one or more of the basic psychological processes involved in understanding or in using language, spoken or written, which may manifest itself in an imperfect ability to listen, speak, read, write, spell, or to do mathematical calculations.. The term includes such conditions as perceptual handicaps, brain injury, minimal brain dysfunction, dyslexia, and developmental aphasia. The term does not include children who have learning disabilities which are primarily the result of visual, hearing, or motor handicaps, or mental retardation, or emotional disturbance, or of environmental, cultural, or economic disadvantage (Hallahan, Kauffman, \& Lloyd, 1996: p. 36-37).

Once a definition was developed for what constitutes as a learning disability, teachers had more to worry about when dealing with their students. If a student was not performing, was it due to a learning disability or was it considered a behavioral problem? These are issues that teachers struggle with today in the classroom.

\section{GENDER DIFFERENCES}

Brophy and Good (1974) discussed that both school personnel and educational psychologists explain school failure as a result of 
social class or some characteristic of a student that is considered unchangeable, such as a student's personality or a student's learning abilities. Instead the teachers and psychologists need to focus their attention on the individual student's "present status, pattern of strengths and weaknesses, methods of approaching problems, and interests", in order to help the student's educational experience be more successful instead of an experience of failure (Brophy \& Good, 1974; p. 3). Different student attributes have been found to influence the teacher's perceptions of students and their patterns of interaction with them in the classroom (Brophy $\&$ Good, 1974). Some attributes can be considered to put the student in an identifiable group, such as social class, race, or sex. While, other attributes tend to be the individual differences, such as classroom behavior and achievement (Brophy \& Good, 1974).

Some research has shown that teachers view girls more favorably than boys (Brophy \& Good, 1974). One finding that has emerged repeatedly is that boys get much more disapproval and criticism from teachers than girls. "Teachers are more likely to use a harsh or angry tone when criticizing boys, while criticism directed toward girls is usually delivered in a more conversational tone” ( $\mathrm{p}$. 13). Teachers tend to act differently to different students. One 
study found that teachers showed more signs of personal involvement with boys than girls, but the statements regarding the boys were negative. These sex-difference findings are typical and can be found in other studies of teacher-student interactions (Brophy \& Good, 1974).

A study by Feshbach (1969) provided information about the types of student attributes that attract or repel teachers. The results of Feshbach's study showed that teachers most preferred the rigid, conforming, and orderly students. The second most preferred were the students who were dependent, passive, and acquiescent. This was followed by flexible, non-conforming, and untidy students. The least preferred students were those who were independent, active, and assertive. Brophy and Good (1974) pointed out the fact that the preferred attributes of a student were those associated with the female sex role, while the rejected attributes were those associated with the male sex role. This suggests that the tendency of teachers to prefer girls to boys is based more on their behavioral differences than on their sex.

Many times teachers enter into a classroom with preconceived ideas concerning the differences between boys and girls. Sex tends to be the most fundamental and pervasive variable that is used to 
divide people into groups (Brophy $\&$ Good, 1974). The reason that teachers have these ideas about boys and girls is because society teaches us that "boys will be aggressive, physically active, and interested in the manipulation of physical objects, while girls will be quieter, more conforming and more interested in verbal and symbolic activities” (Brophy \& Good, 1974; p. 199). Brophy and Good's (1974) summary of research concerning sex differences found the data to suggest:

"that student sex differences should be explained by differences in the attitudes and behavior of the students themselves, and these in turn are to be explained largely by differences in the sex-role expectations and socialization practices that are prevalent in different cultures" (p. 230).

A study by Clarizio and Phillips (1986) examined whether or not there is a sex bias in the diagnosis of learning disabled students. Other studies (Clarizio \& Phillip, 1986) have suggested the reason for a sex bias in the diagnosis of learning disabled students is due to a majority of males in classrooms for learning disabled. The authors wanted to "determine if the sex of the student was a salient factor in the initial diagnosis and placement by multidisciplinary teams in learning disabled programs" (Clarizio \& Phillips, 1986; p. 44). They collected the child's sex, SES, Wechsler Intelligence Scale for Children revised (WISC-R) scores, achievement 
scores in reading, discrepancy between expected and actual achievement, and the reason for referral for 235 children who were diagnosed as LD and 290 children who were declared not eligible for special education. They found there to be an overabundance of males to females that were diagnosed as $L D$, and the males had an average IQ that fell in the lower end of the average range. This study did not find any evidence that indicated that the diagnostic and placement decisions of the multidisciplinary teams were characterized by sex bias. Instead, a "significant interaction between gender and SES and gender and referral reason was found in the not eligible group but not in the LD group suggests that the multidisciplinary teams may have a mitigating effect on initial referral biases" (Clarizio \& Phillips, 1986; p. 51). The authors suggested additional research in order to determine if their results would be different for ethnic minority populations.

A similar study examined other possible student characteristics that might influence team decisions on whether a student is learning disabled. Payette and Clarizio (1994) examined "students' racial, gender, intellectual, achievement, and grade-level status in relationship to misclassification by labeling them LD in the absence of a severe discrepancy or not judging them LD in the 
presence of a severe discrepancy" (p. 41). They collected data on students who were referred for a psychoeducational evaluation because of learning problems. A total of 344 students were included, ranging from kindergarten through twelfth grade. Two groups of misclassified students were identified: those found to be ineligible as LD even though they showed a severe discrepancy between ability and achievement, and those students who were found to be eligible as LD even though a severe discrepancy was not shown. Payette and Clarizio (1994) found that there was not a gender bias on the part of decision makers when deciding whether or not to find a student eligible with the presence of a severe discrepancy. In contrast to this finding, there was an unexpected finding for gender. When they compared the proportions of boys and girls who did not show a severe discrepancy, they found a disproportionate number of girls. The authors did not offer a reason for this finding nor did they discuss it at any length. Payette and Clarizio (1994) offered that school psychologists and other team members need to be more sensitive to gender issues since girls without a severe discrepancy were found more often to be eligible as LD than boys were.

One study examined the prevalence of reading disabilities in 
boys and girls and whether there was a bias in subject selection rather than a gender difference (Shaywitz, Shaywitz, Fletcher, \& Escobar, 1990). The authors hypothesized that there is an increased number of boys than girls with a reading disability due to a bias in subject selection rather than a gender difference. They did this study because physicians were becoming more actively involved in the identification and management of reading disabled children, requiring them to become more knowledgeable about learning disabilities. Two groups were studied. The first group was research identified and the second group was school identified. A total of 445 students participated. The results indicated that there was no significant difference in the prevalence of reading disabilities in the research identified boys compared with research identified girls. The school identification resulted in the classification of significantly more boys than girls.

"These findings are complemented by a series of investigations that indicates that girls with reading disabilities are not as readily identified as boys and, in fact, are more often severely impaired in reading before they are identified for services" (Shaywitz, Shaywitz, Fletcher, \& Escobar, 1990; p. 1001).

An explanation Shaywitz et al. (1990) gave for this statement was that factors not related to a discrepancy between a child's ability and achievement can influence school identification and placement 
for a learning disability. They suggested that "teachers rate boys as significantly more active, more inattentive, and less dexterous and as having more problems in behavior, language, and academics than their female peers" (Shaywitz et al., 1990; p. 1001). Therefore, teachers' perceptions of what constitutes inappropriate behavior enters into the decision and that "over-activity and behavioral difficulties are likely to be disruptive to a classroom and to influence decisions regarding such children” (Shaywitz et al., 1990; p. 1002).

Phipps (1982) examined why a LD learner is often a boy. She noted that boys make up approximately $85 \%$ of the children receiving services in special programs for the learning disabled, educable mentally retarded and behavior disordered in the public schools. There are two main explanations for the over-abundance of boys in these type of programs. The first is biological. One difference is that girls mature at an earlier age than boys. Another biological difference is concerned with aggressiveness, boys seem to be more aggressive than girls. "But differences in permanent biological characteristics, in maturation rates, and in learned cultural role behaviors of the sexes are currently mere speculation insofar as they explain the reasons for the preponderance of boys in special education programs” (Phipps, 1982; p. 426). 
The second is due to the referral process. Phipps (1982)

believes that there is a bias in the reasoning for referral. There are two reasons why a child will be referred to a special program: a behavior problem or an academic problem. A behavior problem was considered to be present when the referral cited conduct, emotional, or social problems. "Academic problems were defined as problems in subject or content areas and related skills" (Phipps, 1982; p. 428). Phipps found that the reason given most often for the referral of boys was due to behavioral problems, and for girls it was due to academic problems.

"The more aggressive child, predictably a boy, has a much greater chance of placement in a special program than a more passive child, who is usually a girl. Management of disruptive children appears to be much more important in the referral and placement process than the academic needs of learning disabled, mildly retarded and behavior disordered, or "emotionally disturbed" children." (Phipps, 1982; p. 430)

From the many different studies concerning learning disabilities and gender, researchers have found that more males than females with learning disabilities are identified; ratios can range from 3:1 to $15: 1$ (Vogel, 1990). It seems that very little is known about females with learning disabilities, and even less about gender differences. The current research suggests that findings based on system-identified samples of children with learning 
disabilities may reflect a sample bias (Vogel, 1990).

Vogel (1990) reviewed previous literature concerning gender differences in students with learning disabilities. She specifically focused on gender differences in normally achieving children and their peers with learning disabilities in the following four areas: intellectual abilities, language functioning, visual-motor ability, and academic achievement. The study (Vogel, 1990) indicated that when females are identified, referred, diagnosed as having learning disabilities, and found eligible for LD services, they (a) are significantly lower in intelligence, (b) are more severely impaired, and (c) have a greater aptitude-achievement discrepancy than their male counterparts. Findings (Vogel, 1990) also indicated that teachers were more likely to refer children for LD evaluation and services if the children had attention deficits and hyperactivity or disruptive behavior, rather than academic under-achievement. "Girls referred for psychological evaluation and with IQs as low as boys remain within regular programs because of the adaptive behavior patterns, while the boys receive special services" ( qtd in Vogel, 1990; p. 48).

Therefore, teacher referrals may reflect a differential attitude due to the adaptive behavior patterns and identify more boys than 
girls as learning disabled. In order for females to be identified for referral and to be diagnosed as having a learning disability, it appears that they must be older and more severely impaired than their male classmates (Vogel, 1990). Other studies concerned with this topic seem to suggest the same evidence (Vogel, 1990).

\section{ATTRIBUTION RESEARCH}

A study by Tollefson, Rodriquez, and Franz (1987) investigated educators' (teacher-trainees, in-service teachers, and graduate students) explanations for the academic success or failure of hypothetical high- and low-achieving junior high-school students with different levels of motivation. They explain from Medway's work (1979) that teachers attribute school-related problems more often to low intelligence or lack of motivation than to poor educational background and quality of teaching. Tollefson, Rodriquez, and Franz (1987) wanted to compare the importance educators, assuming the role of teachers, assigned to effort, ability, teachers' attitudes, and task difficulty as explanations for the success of high ability students and failure of low ability students when the student's motivation was varied. They expected to find ability, effort, and positive attitudes of the teachers to be important 
in explaining the success of high ability students who were described as highly motivated compared to high ability students who were poorly motivated.

Tollefson, Rodriquez, and Franz (1987) surveyed 375 graduate and undergraduate subjects. Vignettes describing six adolescent students with different levels of motivation (low, moderate, high) and achievement-ability (low and high) were presented. "Levels of motivation were crossed with the achievement-ability descriptions” (Tollefson, Rodriquez, \& Franz, 1987; p. 1124). Half of the vignettes used boy's names and the other half used girl's names. The vignettes were then randomly assigned to the subjects. Each subject read the vignette of one boy and one girl. Subjects then rated the importance of four attributions in explaining the students' grades. The results found (Tollefson, Rodriquez, \& Franz, 1987) that ability was viewed as an important factor in explaining both high and low achievement. "High ability was rated as more important in explaining high achievement than low ability was rated in explaining low achievement” (Tollefson, Rodriquez, \& Franz, 1987; p. 1127). Positive attitudes of teachers were viewed as important to the success of the highly motivated student. But, overall ability and task difficulty were more important than the teacher's attitude for 
explaining achievement.

Tollefson, Melvin, and Thippavajjala (1990) completed a study to "(a) validate the attributional categories proposed by Cooper and Good (1983), (b) to determine the relative importance teachers assigned to student, teacher, and environmental factors in explaining academic difficulties, (c) and to describe how teachers report they interact with low-achieving students" (p. 75). The categories that Cooper and Good (1983) established were: ability, previous experience, acquired characteristics, typical effort, interest in the subject matter, immediate effort, attention, teacher quality, task difficulty, other students, family, and physiological processes. These categories were explanations for why students failed or succeeded.

The subjects of Tollefson, Melvin, and Thippavajjala's (1990) study were 20 male and 24 female teachers enrolled in graduate classes in a Midwestern university. They completed a questionnaire that asked them to describe a student with a pattern of low achievement and their feelings and behavior toward the student. There were four parts to the questionnaire that elicited the data they were looking for. Subjects described male students $68 \%$ of the time. Low motivation was the most cited reason for students with 
academic difficulties. Teachers believed a student's failure was under the student's control. The results of this study suggest that an expanded attributional schema is useful in understanding and categorizing the reasons that teachers give to explain why students experience failure in school.

Cooper and Burger (1980) did a study regarding how teachers explain a student's academic performance. There were three different parts to their study. The first part described categorization developed from teachers' explanations for the performance of their own students. Subjects were 39 students from a graduate education course. Each teacher received a booklet containing written instructions and the questionnaire items. They were asked to list three students whom they expected to do poorly and three students whom they expected to do well academically. They were then asked to list why certain outcomes occurred. Twelve categories came out of this. They included: ability, previous experience, acquired characteristics, typical effort, interest in the subject matter, immediate effort, attention, teacher, task, other students, family, and physiological processes. The findings from this part of the study indicate that academic outcomes are hardly viewed as being determined by random processes. 
The second part of the study wanted to identify a smaller number of underlying causal dimensions. The authors really wanted to uncover a possible teacher efficacy dimension. In other words they wanted to view teachers having an influence over the performance outcome. They asked prospective teachers how the "attributions would influence their intended feedback to the student, whether the attribution would lead to a change in their style of teaching, and whether they would work more or less with the student based on the cause of performance" (Cooper $\&$ Burger, $1980 ;$ p. 100). From this part of the study Cooper and Burger (1980) found that internal, unstable causes elicited the greatest intention to criticize. Internal, stable causes lead to wanting to spend more time with the students. If the teacher saw a failure as potentially avoidable through personal intervention, then behavior would change.

For the third part of the study teachers were asked to supply four causal profiles interpreting the successes and failure of both high- and low-expectancy students. Cooper and Burger (1980) wanted to determine whether the earlier findings were true when a change in the methodology occurred. They found that bright student failure was more often attributed to immediate effort, while 
ability was seen as the cause for slow student failure.

A study by Bar-Tal and Darom (1979) examined a student's attributions to their own success and failure in a real classroom setting. They examined the effects of attributional tendencies on sex differences. It was predicted that success would be attributed more to internal causes, and failure would be attributed to external causes. Previous studies have shown that females differ from males in the causes of their success and failures (Bar-Tal \& Darom, 1979). Subjects were 236 fifth- and sixth-grade students. The researcher went to the school on the day the teacher returned a graded test to the students. A questionnaire was given out asking the students to evaluate the grade they received and asking them to evaluate the degree to which each cause influenced the grade they received. The influential causes included: ability and interest in the subject matter, effort exerted during the test and preparation for the test at home, difficulty of the subject material, difficulty of the test, conditions in the home, and the teacher's explanation of the material. Results (Bar-Tal \& Darom, 1979) found that girls tended to attribute their outcome to preparation and home conditions, which are considered internal-unstable causes. Successful boys attributed their outcome more to ability, which is considered to be 
an internal-stable cause, than did successful girls. The students who succeeded attributed their outcome to ability, ease of subject material, ease of the test, teacher's explanation, and home conditions (Bar-Tal \& Darom, 1979; p. 265). This study suggests Weiner's (1972) assumption that individuals tend to use four causes for explaining success and failures may be too limiting. This study demonstrated that individuals use more than the prevalent four causes of success and failure.

Graham and Brown's study (1988) proposed that teachers may use their knowledge concerning effort and ability differently when making judgments about students based upon the type of judgment that is needed. If a teacher has to make a judgement about a failing student, she/he has to decide whether the need to reprimand the student for poor performance is based on how hard the student tried or how smart the student is. Graham and Brown (1988) contended that in this situation, the teacher will base the judgement upon effort rather than ability. If a teacher needs to judge the same failing student for future performances, knowledge of the student's ability will be the more useful causal cue.

Graham and Brown (1988) tested this hypothesis by measuring the amount of time it would take to make evaluative and 
expectancy judgments given various combinations of ability and effort information. They predicted that judgements about blame following failure would be faster when the teacher has information concerning effort rather than ability. Judgements about expectancy would be faster when the information available concerned the student's ability rather than effort. Researchers presented subjects with a stimulus sentence indicating that a student failed a test and varied the level of ability and effort information. Subjects then responded to an evaluation, expectancy, or affect question calling for a "yes" or "no" response, and the time it took to respond was recorded. The results (Graham $\&$ Brown, 1988) supported the hypothesis. Judgments of blame and pity were made the quickest when effort information was provided. Expectancy judgments were reached the quickest when ability information was provided. The implications this study has is that the informational value of these causes may vary depending upon the perceiver's processing goal. The information that teachers receive about a particular student deals with ability, effort, motivation, prior classes the student has attended, previous teacher, and so on. Generally, the teacher already makes a judgement about a particular student based on this information, even before the student is in the 
classroom (Rolison \& Medway, 1985). If the student is labeled learning disabled or mentally retarded, it would be expected that the teacher's expectations would be lower. This initial bias towards a student can effect that student's achievement level, but the bias can be overcome when the actual performance is inconsistent with the information conveyed by the label (Rolison \& Medway, 1985). Rolison and Medway (1985) examined the effects of “(a) student special education label (no label, learning disabled, or educable mentally retarded), (b) past performance pattern, and (c) previous participation in special education (no participation, resource room, self-contained classroom) on teachers' expectations regarding future academic performance” (p. 562). Rolison and Medway (1985) hypothesized that "expectations for educable mentally retarded students would be lower than those for learning disabled or nonlabeled students" (p. 562). It was also hypothesized that the more intensive the prior special education placement, the greater the stigma and the lower the future expectations. They believed that expectations would be higher for students who performed better later in the term than students who performed successful at the beginning of the term. A second focus of their study was to examine teacher's causal attributions as a function of the three experimental 
manipulations. They believed that labels and previous performance would influence teachers' attributions.

Subjects were given booklets that provided varying information about a hypothetical student. The sex of the student was not manipulated. On the first page subjects were asked to give their age, sex, race, length of elementary teaching experience, and present teaching assignment. The second page had general information regarding the hypothetical student and contained different information regarding the student's label and previous education placement. The third page contained information regarding the student's previous performance pattern. After all the information was read, subjects were asked questions about future expectations and causal attributions regarding the student's performance. The results of the study (Rolison $\&$ Medway, 1985) can be summarized by saying that the failure of low aptitude students is attributed to low ability, whereas the failure of nonlabeled children is attributed to low effort or some external cause. These results indicate that teachers raise or lower their expectations according to a student's previous special education label and past performance.

A similar study examined teacher's expectations and the effect 
these expectations have upon the student (Jussim, 1989). Jussim (1989) explained that teachers develop expectations for the performance of their students early in the year, and that students generally confirm these expectations. That is, students believed to be high achievers often perform at higher levels than students believed to be low achievers. Jussim (1989) compared three explanations for why students confirm teachers' expectations. They include self-fulfilling prophecies, perceptual biases, and accuracy. Self-fulfilling prophecies may occur when a teacher's expectations are initially wrong because "teachers may evoke from students performance levels consistent with those expectations" (Jussim, 1989; p. 469). Perceptual biases can be derived from teachers' expectations when there is a tendency by the teachers to interpret, perceive, remember, or explain the student's actions in ways that are similar to the initial expectations. "Accuracy refers to successfully predicting achievement without influencing it" (Jussim, 1989; p. 469).

Subjects in this study included both teachers and students of sixth-grade math classes. Teachers were asked to evaluate each of their students in class at the beginning of the year, based on the student's talent, effort, and performance in math. Students also 
participated by filling out questionnaires assessing their own beliefs, perceptions, and feelings concerning their self-concept of ability in math, effort in math, the time they spend on math homework, and the value they place on math (Jussim, 1989; p. 471). The final grades in the student's fifth-grade math class and scores on the math section of a standardized achievement test taken in the first week of sixth grade were also obtained in order to measure achievement. Two findings (Jussim, 1989) concerning teacher expectations and student motivation were discussed. The first finding was that a teacher's perception of performance had a selffulfilling effect on a student's self-concept of ability. The second finding showed that "motivation did not mediate effects of teachers' expectations on students' performance” (Jussim, 1989; p. 476). These particular findings appear to support previous research (qtd. in Jussim, 1989) that the expectations teachers have of their students predict future performance and motivation. Jussim (1989) concludes that “teachers' perceptions of students' performance affect the feedback they provide, which in turn affects students' selfconcept of ability” (p. 476).

Graham (1990) examined how teachers' attributions towards students can have a negative effect upon the student even if the 
communication of the attribution is unintentional. She explained that unintended communication of attribution information is likely to occur when the teacher wants to protect the self-esteem of a failure-prone student. Graham (1990) argued that three prevalent and positive teacher behaviors can be conceptualized to unintentionally function as low-ability cues. These behaviors include communicating pity following failure, the offering of praise following success, and unsolicited offers of help. She contrasted these feedback types to three equally prevalent but negative teacher behaviors that could indirectly communicate the more adaptive lack of effort attribution. These behaviors include communicating anger following failure, the assignment of blame following failure, and the withholding of help.

Graham described four principles for explaining why teachers communicate certain attributions. The first is that some emotions are responses to causal attributions, or in other words our thoughts determine how we feel. Pity and anger are common emotions that share in the fact that they are determined by causal thought. For example, when a person perceives another's failure as caused by uncontrollable causes, such as low ability, that person will feel pity. But on the other hand, when a person perceives another's failure 
due to controllable factors, such as lack of effort, then anger will arise within the person. This principle is similar to many of Weiner's $(1972,1977)$ arguments concerning a person's perception of another when examining controllable versus uncontrollable variables. The second principle is that attributions determine achievement evaluation. For example, praise and blame from others allow us to infer about the effort expended as the cause for either success or failure. Third, ability and effort can be viewed as conditional causes of achievement. Praise can lead a person to infer high effort, but the higher one's perceived effort, the lower one's perceived ability. On the other hand blame can lead a person to infer low effort, and the lower one's perceived effort, the higher one's perceived ability. The fourth principle is that helping behavior is often a response to a particular attribution. For example, a person is more willing to help someone when they see the cause of the need due to uncontrollable factors rather than due to controllable factors. This study shows that even if a teacher's behaviors are positively motivated, the behaviors can still illicit low-ability cues to students.

Several studies demonstrate that teacher attitudes and predictions about future behavior are influenced by a student's facial attractiveness, achievement level, sex, race, socioeconomic 
status, and classroom behavior (Stoller, Algozzine, \& Ysseldyke, 1981). A special education label also seems to influence a teacher's attitude and future expectations. Stoller et al. hypothesized that "teacher expectations for the future performance of a child and teacher attributions for that performance would not differ as a function of the categorical label assigned to the child (either LD or educationally handicapped $(\mathrm{EH}))$ or of his perceived competence (high or low)" (p. 54). Participants in this study were 40 special education teachers. They each viewed a short videotape and reviewed a brief case history for the child observed. They were then asked to fill out a questionnaire asking them to ascribe causal attributions to the child's performance. The independent variables of label and competence were manipulated yielding four types of children that the subjects could have viewed. The results concluded that the attributions teachers made for future expectations of performance by the child and the child's behavior were different when the child was seen as having either more or less competence (Stoller et al., 1981; p. 58). 


\section{CONCLUSION}

From the review of the literature concerned with learning disabilities, gender differences, and attribution research, it can be concluded that something is missing. Specifically, research that combines the variables of learning disabilities, attributional tendencies, and gender biases. This study will combine these variables in order to better understand teachers' attributional tendencies towards their failing students.

The next chapter will examine the theory behind attribution research and gender differences, and how these theories apply to this study. 


\section{CHAPTER II}

\section{THEORETICAL PERSPECTIVES}

\section{INTRODUCTION}

This chapter will discuss the background of attribution theory and how it will apply to this particular study. A short discussion of gender theory and why there might be differences between males and females will also be added. Finally, there will be a discussion of what this study plans to examine and a list of hypotheses.

\section{ATTRIBUTION THEORY}

Attribution theory (Jones, Kanouse, Kelley, Nisbett, Valins, \& Weiner, 1972) is concerned with the reasoning that people give to explain their own behavior and the behavior of others. This theory will be used to focus on the explanations that teachers give for students' success or failure. Four main theories have been developed from which major concepts are used in today's research concerning attribution. The authors of these main theories include Heider, Kelley, Jones and Davis, and Weiner.

Heider's theory (1958) attempted to explain naïve psychology, which is the process by which an untrained observer makes sense 
of the physical and social world. Though he never developed a theory of attribution, the principles behind explaining naïve psychology have guided future theories. Kelley's covariation model (1972) is directly influenced by Heider. The covariation principle states that "an effect is attributed to the one of its possible causes with which, over time, it covaries" (Kelley, 1972; p. 3). Kelley is concerned with multiple observations of behavior, and whether a behavior is caused by an actor or by the environment in which the actor is involved. The attribution of cause is based on consensus, distinctiveness, and consistency. Consensus means that many people would act in a certain situation the same way.

Distinctiveness means that the person acts differently in other situations. Consistency means that the person has acted in the same way. These three types of information are combined and used to support whether the behavior should be attributed to the actor, internal, or the environment, external (Kelley, 1972). Jones and Davis' (1965) purpose for developing the theory of correspondent inference was to "systematically account for a perceiver's inferences about what an actor was trying to achieve by a particular action" (p. 222). Jones and Davis are trying to assess the degree to which an observer can be sure that a given behavior is caused by a specific trait. In other words they want to account for when to attribute a 
trait to an actor on the basis of a specific behavior. Finally, Weiner's theory $(1972,1977)$ of attribution is concerned with the causes of success and failure. Weiner's theory is the most pertinent to this study and will be discussed more in depth.

Weiner's theory $(1972,1977)$ focuses on three dimensions to analyze the kinds of attributions people give for their behavior and the behavior of others. The first dimension consists of a stability dimension. Behavior can be explained by using stable versus unstable causes. The second dimension is whether the cause is considered to be internal or external to the person. The third dimension is an issue of controllability. The explanation of the behavior could be due to controllable or uncontrollable causes. These three dimensions can help predict how people view the causes of success and failure (Weiner, 1977).

Ability, effort, task difficulty and luck are the four primary causal attributions for explaining a person's success or failure (BarTal \& Darom, 1979; Cooper \& Burger, 1980; Graham, 1990;

Tollefson, Melvin, \& Thippavajjala, 1990; Weiner, 1974, 1977). These four factors can be classified as internal or external, as stable or unstable and as controllable or uncontrollable (Cooper $\&$ Burger, 1980; Graham, 1990; Weiner, 1990). Ability is internal, stable, and uncontrollable, while effort is internal, unstable, and controllable. 
Task difficulty is external, stable, and uncontrollable, and luck is external, unstable, and uncontrollable (Tollefson, Rodriquez, \& Franz, 1987). The current research is only concerned with ability and effort, and how these two factors can be used in a teacher's explanation of their student's failure.

Ability and effort differ in stability and controllability. Weiner and his colleagues (1974) labeled the property that distinguished ability and effort as causal stability. Ability is considered to be fixed, while effort is seen as variable and able to change over short periods of time. Causal stability can be related to expectations for the future (Graham \& Brown, 1988). Graham and Brown (1988) point out that if the causes of events are likely to remain stable (i.e. ability), then a person can be more certain that these events are more likely to occur again than if the causes are subject to change (such as effort). These authors also discuss causal controllability, but instead of being related to future expectations it is related to interpersonal evaluation (Graham and Brown, 1988). They use an example that when a student is blamed or punished more by their teacher when they fail, that it is due to a personal controllability cause such as lack of effort. Effort, perceived as a controllable cause, means responsibility, whereas ability, a perceived stable cause, means repetitiveness. 
Weiner $(1972,1978,1990)$ concluded that the

evaluation of a person is influenced by the perceived amount of effort that was expended. Higher effort would be rewarded in achievement settings, while lower effort tended to be punished.

\section{SUMMARY}

Attribution theory helps to predict the causes that people will use to explain their behavior and the behavior of others. Ability, effort, task difficulty, and luck are the four primary causes used to interpret and predict the success or failure of a person. When these causes are put into the three dimensional categories from Weiner (1974), then the ability to predict the success or failure of a person increases.

\section{APPLICATION OF ATTRIBUTION THEORY}

Graham and Weiner (1986) established a connection between anger/pity and reward/punishment. They found that anger/pity and reward/punishment are established based on one's ability and effort. Graham and Weiner (1986) concluded that classroom teachers may feel anger toward a child who failed due to lack of effort, especially if that child has high ability, but they would feel pity towards a child who failed due to low ability. The teacher views 
a child with high ability as being in control of their own effort and outcome, and therefore feels anger when the child fails, while the same teacher will feel pity for a child that is unable to control their own ability (Graham $\&$ Weiner, 1986). With this in mind, the teacher is more likely to punish the low-effort child while rewarding the low-ability child. A child with learning disabilities will encounter low-ability and the teacher will most likely perceive this child's performance as stable, but uncontrollable. Therefore, the teacher will feel more pity towards this child and will reward him more (Clark, 1997).

Clark (1997) examined general education teachers' responses to a hypothetical boy's failure with and without a learning disability. She wanted to see whether the knowledge of a learning disability influenced the teacher's level of reward or punishment they gave the child, whether the teacher felt pity or anger, and the type of expectations the teacher felt for the child's future. The subjects of this study were 97 general education classroom teachers from public elementary schools. Each subject read 8 vignettes describing a hypothetical boy who had just taken a typical classroom test and failed. The vignette included information describing the student's ability, the typical pattern of effort, and additional information on academic performance identifying four of the boys as learning 
disabled and four as non-disabled. After reading each vignette, the teachers were presented questions asking them to provide evaluative feedback, rate their anger and pity, and rate their future expectations for the student. Clark (1997) found that teachers believe that students with learning disabilities will fail more, are deserving of more pity, and should be rewarded more than their non-disabled peers.

\section{SUMMARY}

According to Graham and Weiner (1986), teachers view their students differently based upon the student's ability and effort. Clark (1997) added to this finding by adding learning disabilities as another cause for failure. It was found that there was a difference between the attributional tendencies of teachers who view learning disabled and non-disabled students. By adding another variable, the question is will there also be a difference between male and female learning disabled and non-disabled students?

\section{GENDER THEORY}

According to the literature previously discussed (Clarizio \& Phipps, 1986; Payette \& Clarizio, 1994; Phipps, 1982; Shaywitz, Shaywitz, Fletcher \& Escobar, 1990), there appears to be a gender 
bias in the diagnosis of learning disabled students, although there is some controversy concerning where the bias occurs (Clarizio \& Phipps, 1986; Payette 8 Clarizio, 1994; Phipps, 1982; Shaywitz et al., 1990; Vogel, 1990), whether it is strictly gender differences or whether it is in the process of the diagnosis. A higher percentage of males are considered learning disabled than females. In general, there appears to be a gender bias in the classroom, whether the students are learning disabled or non-disabled.

There seems to be certain expectations for the way that females and males should behave. Males should be aggressive, while females should be passive (Brophy \& Good, 1974). Where are these behavioral expectations derived from, and how do they effect the classroom? Society teaches children the types of roles they are made for based on whether they are male or female (Lengermann \& Niebrugge, 1996; Restivo, 1991). Society is male dominated and has a history of patriarchy. This domination has been argued to be based in social organization or institutions and the culture (Restivo, 1991). The way to change the domination is by changing what occurs in the institutions, but this cannot happen until behavioral expectations are erased (Restivo, 1991). Behavioral expectations affect the classroom due to the tendency of males receiving more 
attention, whether it is positive or negative, and are called on more often by teachers than are females (Brophy \& Good, 1974).

Behavioral expectations play a part concerning the teachers' perceptions of their students, whether it is favorable or nonfavorable. Teachers' perceptions based on expectations will also help determine how much a teacher will pity, be angry with, reward or punish, and expect future failure for a student in their classroom.

\section{SUMMARY}

This section discussed the fact that there are certain expectations for males and females. It also alluded to some different reasoning for why this occurs. Perhaps it is these expectations for males and females that allow for a gender difference within learning disabled students. From the attribution research it was concluded that teachers attribute success and failure to learning disabled and non-disabled students differently. From gender research it was concluded that males and females are diagnosed differently. Therefore, a difference should be found for how teachers will attribute a student's success or failure based on whether the student is male or female, learning disabled or non-disabled. 


\section{HYPOTHESES}

With the ideas of attribution theory, research concerning gender bias of students, and research concerning learning disabled students tied into both attribution theory and gender bias, this research plans to examine teachers' attributional tendencies and gender bias towards learning disabled students. The following is a list of the hypotheses this study plans to test.

1. Teachers will attribute reward, anger, pity, and expectancy for future failure differently for the hypothetical female and male students.

2. Teachers will reward female students with learning disabilities more often than male students with learning disabilities.

3. Teachers will exhibit a lower rate of anger for female learning disabled students than their male counterparts.

4. Teachers will exhibit a higher rate of pity for female learning disabled students than their male counterparts.

5. Teachers will have higher expectations for future failure by males with learning disabilities than females with learning disabilities.

6. These differences between male and females will also exist in the students without learning disabilities. 
7. Teachers will attribute reward, anger, pity, and expectancy for future failure differently for the hypothetical learning disabled and non-disabled students.

\section{CONCLUSION}

This chapter examined attribution theory and how it applies to this study. There was also a discussion concerning gender theory and why there might be a difference between males and females. Finally, a list of the hypotheses were compiled together. The following chapter will discuss the subject selection, instrument development, procedure, and how the independent and dependent variables are measured. 


\section{CHAPTER III}

\section{METHODOLOGY}

\section{INTRODUCTION}

This chapter will discuss the subject selection, instrument development, procedure, independent and dependent variables, and the measurement techniques that will be used for data analysis.

\section{SUBJECTS}

The subjects included 80 students from Portland State University enrolled in the School of Education. The School of Education has a total of 615 students enrolled in masters and doctoral programs. The majority of the students (538) are enrolled in the masters program. The students range in age between 21 and over 56, with the average age being approximately 36 years old. Females outnumber the males 2 to 1 ( 428 and 187 respectively). The largest ethnic group is the European American with a total of 495 students. The next largest groups are the Hispanic and Black with 24 and 23 total students. More of the students enrolled in the School of Education are considered part time students (316) than they are considered full time students (299). 
The reason students were used was because of convenience, and many of them had teaching experience and were going back to school for more education, or were just starting their teaching career. It was easier to reach this population than teachers employed in schools considering their time constraints.

\section{INSTRUMENT}

Eight vignettes were used, describing a hypothetical student who had just failed a test given in the classroom. The vignettes were taken from Clark's study (1997). The only difference was that boys' and girls' names were used to describe the hypothetical students, whereas Clark only used boys' names. There were two forms of the survey, which were randomly handed out. Both forms had a certain combination of vignettes involving a male/female variable. This was the only variable that differed between the forms. The different forms were used in order to offset and control for any confounding variables that might exist. The vignettes included information about the students' ability, the typical pattern of effort given by the students in the classroom, and additional information on academic performance identifying half of the students as learning disabled and the other half as non-disabled. The students were matched on ability (high or low), on typical effort (high or low), 
on the presence or absence of a learning disability (LD/NLD), and on their gender (male/female). The following is an example of a high ability, low effort, learning disabled student. (See appendix A for a complete list of the vignettes and questions.)

Jim is a student in your class. He is a rather bright boy but has some difficulty with comprehension, both in math and in reading. He sees the resource specialist for assistance with his comprehension difficulties; He does the majority of his class work quickly, often making many errors. Homework is done the same way unless a parent supervises him. His participation in group work varies but is usually limited. He has just failed your most recent test.

As can be seen from the vignette, it does not use the words high ability and low effort, rather it uses wording that a teacher might encounter. In Clark's study, a pretest was performed in order to verify the wording of these vignettes. She found that the wording was correct and the teachers knew when the student was learning disabled or non-disabled by whether or not the student was going to a resource specialist.

After the subjects read each vignette, there were four questions asking them to (1) provide evaluative feedback, (2) rate their anger, (3) rate their pity, and (4) rate their expectations following each failure. Responses were measured on Likert scales. An open-ended question was added asking them what factors helped make their decisions for the above questions. This question 
was designed to elicit additional comments concerning why a student might fail and why a teacher would feel a certain way towards that particular student. At the end of the survey, they were asked to give descriptive data regarding their age, gender, education level, if they had any teaching experience, whether they were in general education or special education, and additional space was provided for any other written comments.

\section{PROCEDURE}

Data was collected in both special education and general education classes given in the School of Education. The professors of certain classes were first contacted and explained to what the research project was concerned with, and asked if it would be possible to hand out the survey to their students. Once permission was given, a time was set for the next class time when the survey could be presented to the students. The students were given 20 minutes to fill it out. The surveys were generally handed out at the beginning of the class period. One class was unable to take that much time out of the period, so an explanation was given of the survey and it was handed out with the expectation that the students would return it the following week. 
Before the survey was handed out to the students, a brief

explanation was given. They were told the purpose of this study was to examine teachers' attitudes towards failing students. It was explained that they would need to read eight vignettes and answer five questions after each vignette, and this should take approximately 15-20 minutes. A statement of informed consent (see appendix B) was handed out to the students prior to filling out the survey explaining that all information would be kept confidential and that their names would not be used. The informed consent was explained and the students were told to read through it, and if they understood and were willing to participate in the study they needed to sign their name. After this was completed, the surveys were handed out to the people that had signed the consent form. After the surveys were completed, they were picked up along with the signed informed consent form, and the subjects were thanked for their time. The survey and the consent form were kept separately so as to insure confidentiality.

\section{INDEPENDENT VARIABLES}

The variables that were considered as independent included: ability, effort, gender, and learning disability. All of the independent variables were based on a dichotomous scale. Ability was scored as 
either high or low ability. Effort was scored as either high or low effort. Gender was either male or female. The variable learning disability was scored as either the student having a learning disability or not having a learning disability.

Other independent variables examined included demographic information: age, sex, education level, teaching experience, level respondent has taught, number of years taught, and the type program the respondent was enrolled in. The education level was divided into 6 categories: $1^{\text {st }}$ years Masters, $2^{\text {nd }}$ years Masters, Masters degree, Ph.D. in progress, Ph.D., and other. Teaching experience had a "yes" or "no" answer. If respondents did have teaching experience, they were asked at what level they have taught. Three choices were given for this question: elementary, middle, and high. The next question asked them how long they have taught in years. The question concerning which program they were enrolled in had three answer choices: general education, special education, and other.

\section{DEPENDENT VARIABLES}

The four dependent variables consisted of the amount of reward respondents would score a given student, level of anger towards a student, level of pity, and expectations for future failure 
from a student. The amount of reward was based on a Likert scale ranging between 1 (negative feedback) to 7 (positive feedback). The level of anger and pity towards a student was also based on a Likert scale ranging between 1 (very little) to 7 (very much). The last variable asked respondents to predict how likely a particular student will fail on future tests, and this was scored on a Likert scale ranging between 1 (very unlikely) to 7 (very likely).

\section{CONCLUSION}

This chapter discussed subject selection, instrument development, procedure, and how the variables were measured. In the following chapter it will discuss the use of statistical tests in order to analyze the data, and will examine each dependent variable separately to understand the effects they each have. This will also test the different hypotheses. 


\section{CHAPTER IV}

\section{FINDINGS}

\section{INTRODUCTION}

This chapter will examine the statistical tests that were used to analyze the data and will examine each of the dependent variables. First, a discussion of the subjects' demographics will be presented. Following will be the findings from each dependent variable and how it relates to the hypotheses.

\section{DEMOGRAPHIC STATISTICS}

A total of 80 subjects were given the survey, 52 females and 23 males that completed the survey ( 5 respondents did not complete this answer). The average age of the subjects was approximately 30 years of age. Over half of the subjects $(52.5 \%)$ were teaching in a special education program, while $26.3 \%$ taught general education and the other $21 \%$ were either in another program or did not answer the question. Half of the respondents $(50 \%)$ were in their $1^{\text {st }}$ year of a Masters program, $5 \%$ were in their $2^{\text {nd }}$ year of a Masters program, $27.5 \%$ had their Masters degree, $1.3 \%$ had a Ph.D., and 5\% had a different degree other than a Masters or Ph.D. (9 respondents did 
not complete this question). Out of 80 subjects, $85.0 \%$ had some teaching experience (again there were 5 respondents that did not complete this answer). The average number of years taught was 5.1 , with a range between 0 and 27 years. The percentage of subjects that taught at the elementary age level was $35 \%, 21.3 \%$ have taught at the middle school level, $27.5 \%$ have taught at the high school level, and $2.6 \%$ have taught at college level or at another level (again there were 11 respondents that did not complete this question).

\section{REWARD}

The first question examined asked for teachers' feedback towards certain students, and whether they would give positive or negative feedback. Positive feedback is designated as reward, whereas negative feedback is considered punishment. It was hypothesized that teachers would reward female students with learning disabilities more than male students with learning disabilities, and in general more female students than male students. When examining only the mean responses to this question, it was found 6 out of 8 times that females were given 
more positive feedback than their male counterparts. Table 1 presents the mean responses and standard deviations for reward.

TABLE 1

Mean Teacher Responses to Reward Question

HIGH ABILITY

High

Effort

LD $\quad \begin{gathered}\mathrm{M}=5.19 \\ \mathrm{SD}=1.18\end{gathered}$

MALE

$\begin{array}{ccccc} & \begin{array}{c}\text { High } \\ \text { Effort }\end{array} & \begin{array}{c}\text { Low } \\ \text { Effort }\end{array} & \begin{array}{c}\text { High } \\ \text { Effort }\end{array} & \begin{array}{c}\text { Low } \\ \text { Effort }\end{array} \\ \text { LD } & \mathrm{M}=5.19 & \mathrm{M}=4.94 & \mathrm{M}=5.17 & \mathrm{M}=4.21 \\ & \mathrm{SD}=1.18 & \mathrm{SD}=1.39 & \mathrm{SD}=1.53 & \mathrm{SD}=2.24\end{array}$

NLD

$\begin{array}{ccccc}\text { NLD } & \mathrm{M}=4.79 & \mathrm{M}=4.07 & \mathrm{M}=5.51 & \mathrm{M}=4.65 \\ & \mathrm{SD}=1.65 & \mathrm{SD}=1.27 & \mathrm{SD}=1.48 & \mathrm{SD}=1.29 \\ & & & & \\ \text { LD } & \mathrm{M}=5.48 & \mathrm{M}=4.63 & \mathrm{M}=5.43 & \mathrm{M}=4.60 \\ & \mathrm{SD}=1.14 & \mathrm{SD}=1.52 & \mathrm{SD}=1.50 & \mathrm{SD}=1.65\end{array}$

FEMALE

$\begin{array}{ccccc}\text { NLD } & \mathrm{M}=5.02 & \mathrm{M}=4.17 & \mathrm{M}=5.46 & \mathrm{M}=4.76 \\ \mathrm{SD}=1.45 & \mathrm{SD}=1.58 & \mathrm{SD}=1.02 & \mathrm{SD}=1.58\end{array}$

Note. $\mathrm{LD}=$ learning disabilities; $\mathrm{NLD}=$ no learning disabilities. Reward scale: 1 (negative feedback or reward) to 7 (positive feedback or reward).

The scenarios where the males had more positive feedback were high ability, low effort, learning disabled, and low ability, high effort non-learning disabled. When a female was considered to be of high ability, high effort; low ability, high effort; low ability, low effort; and learning disabled, she tended to receive more positive feedback. The female non-disabled student received more positive feedback when she was considered to be of high ability, high effort; high 
ability, low effort; and low ability, low effort. A possible explanation for why the male learning disabled student received more reward when he had high ability and low effort; and why the male nondisabled student received more reward when he had low ability and high effort might be explained due to the unequal number of surveys handed out to the subjects. Two different forms were handed out, yet there was an unequal number that completed each survey. Another explanation might be that there is a gender bias occurring, where teachers would give more positive feedback to a high ability, low effort, learning disabled male because they want him to succeed. This could also be the case for the non-disabled male. Yet, on the other hand if this was truly occurring, the males would have received more positive feedback on the whole. Possibly an interaction between the variables might be occurring, and this would be another explanation for the differences. Interactional effects will be examined more thoroughly later in this chapter.

Since the differences among the mean responses are not very large, it is necessary to examine statistical tests in order to determine significance among the variables. The first statistical test was a one-way analysis of variance (ANOVA) with reward as the dependent variable and sex, learning disability, ability, and effort as 
the independent variables. The ANOVA is able to show any differences among a set of group means. The one-way ANOVA only examines main effects and does not look at interactional effects. Main effects look at the separate independent variable effects, whereas interactions examine how two or more independent variables influence a dependent variable. The $\mathrm{F}$ ratio is a ratio of two mean squares, or in other words the ratio of the between estimate to the within estimate of variance. Table 2 presents the mean squares, degrees of freedom, and $\mathrm{F}$ ratio for the ANOVA.

TABLE 2

One-way ANOVA with Reward as Dependent Variable

\begin{tabular}{|c|c|c|c|}
\hline $\begin{array}{c}\text { Independent } \\
\text { Variable }\end{array}$ & D.F. & $\begin{array}{c}\text { Mean } \\
\text { Squares }\end{array}$ & F Ratio \\
\hline Sex & 1 & 2.75 & 1.115 \\
\hline LD & 1 & 3.60 & 1.50 \\
\hline Ability & 1 & 5.62 & 2.35 \\
\hline Effort & 1 & 90.00 & $39.94^{*}$ \\
\hline${ }^{*} \mathbf{p}<.001$ & \multicolumn{3}{|c}{}
\end{tabular}

A main effect for effort, $F(1,80)=39.94, p<.001$, was found for the amount of reward or punishment given to a hypothetical student. A higher rate of reward was given to the student who was perceived as having a high rate of effort, than to the student who was considered to be of lower effort. 
A regression analysis was also completed in order to examine the effects and the size of the effects of the independent variables upon the dependent variable. Table 3 presents the Beta coefficients, $\mathrm{T}$ statistic, and the significance of $\mathrm{T}$ for each independent variable as they were entered into the regression equation. The Beta coefficient measures the relative weight attached to the various independent variables in contributing to the mean of the dependent variable. The larger the value of Beta, the greater is the effect on the dependent variable that is produced by a standard deviation change in the independent variable, controlling for the other variables. The T statistic is used to test the null hypothesis that there is no linear relationship between the dependent variable and the independent variable. If the significance level is less than .05 or .01 , the null hypothesis that there is no linear relationship between the dependent and independent variable, is rejected. 
TABLE 3

Regression with

Reward as Dependent Variable

\begin{tabular}{|c|c|c|c|}
\hline & Beta & $\begin{array}{c}\text { T } \\
\text { Statistic }\end{array}$ & $\begin{array}{c}\text { Signif. Of } \\
\mathbf{T}\end{array}$ \\
\hline Effort & .242 & 6.332 & $.001^{*}$ \\
\hline Ability & -.060 & -1.583 & .113 \\
\hline Sex & -.042 & -1.108 & .268 \\
\hline LD & .048 & 1.266 & .205 \\
\hline
\end{tabular}

Note: $\mathrm{R}$ Square $=.0667$

${ }^{*} \mathrm{p}<.001$

Again, effort appears to have the strongest relationship for the amount of reward or punishment given. The negative numbers for ability and sex show the direction of the relationship. The $R$ Square of .0667 is considered weak and means that the combination of the independent variables does not help explain changes in the value of reward very much. As can be seen from the table, effort explains almost all of the variance in reward.

\section{ANGER}

The second question asked respondents to rate their anger for each hypothetical student. The scale was based on a Likert scale with 1 meaning very little anger, and 7 meaning very much anger. It was hypothesized that teachers would have a lower rate of anger towards female learning disabled students specifically, and female students and learning disabled students generally. The mean 
scores were examined for this question. Table 4 presents the mean scores and the standard deviations for question asking teachers to rate their anger.

TABLE 4

Mean Teacher Responses to Anger Question

MALE

HIGH ABILITY

High

Effort

LD $\quad \begin{gathered}\mathrm{M}=1.26 \\ \mathrm{SD}=.774\end{gathered}$

\section{Low Effort}

High Effort

$\mathrm{M}=1.21$

$\mathrm{SD}=.791$
LOW ABILITY

$\mathrm{SD}=.969$

$M=1.05$

$M=2.02$

NLD

$M=1.15$

$\mathrm{SD}=.539$

$\mathrm{M}=2.34$

$\mathrm{SD}=.223$

$\mathrm{SD}=1.33$

LD $\quad \begin{gathered}\mathrm{M}=1.10 \\ \mathrm{SD}=.307\end{gathered}$

$$
\mathrm{M}=1.51
$$

$\mathrm{M}=1.05$

$\mathrm{M}=1.87$

$\mathrm{SD}=.925$

$\mathrm{SD}=.223$

$\mathrm{SD}=1.43$

FEMALE

$$
\begin{array}{ccccc}
\text { NLD } & \mathrm{M}=1.26 & \mathrm{M}=2.07 & \mathrm{M}=1.26 & \mathrm{M}=1.64 \\
\mathrm{SD}=.775 & \mathrm{SD}=1.34 & \mathrm{SD}=.775 & \mathrm{SD}=1.22
\end{array}
$$

Note. $\mathrm{LD}=$ learning disabilities; $\mathrm{NLD}=$ no learning disabilities. Anger scale: 1 (very little) to 7 (very much)

Respondents rated themselves as having the most anger with the hypothetical students when they were considered to be of high ability, low effort, non-disabled males (mean score of 2.34); high ability, low effort, non-disabled females (mean score of 2.07): and with students considered to be of low ability, low effort, nondisabled males (mean score of 2.02). The mean scores are low on the scale meaning the respondents in general did not have much 
anger towards any students. It is interesting to note that between the female and male learning disabled, there was a higher mean rate of anger for the females when they were of low effort. A higher mean rate of anger was given to the male learning disabled students when they were of high effort. The opposite was true when examining the differences between female and male non-disabled students. A possible explanation could be due to interactional effects of two or three of the variables. Again, this will be discussed later in this chapter. An ANOVA was completed to examine anger with other independent variables, such as the demographic questions. It was found that the age of the subject was significant, $F(27,79)=2.75$, $\mathrm{p}<.001$, and helped explain the variance in anger for all of the situations. Perhaps, part of the reason for the different scores could be explained by the age of the subject.

Due to low differences between the means, an ANOVA was again performed in order to determine significance. Table 5 presents the mean squares, degrees of freedom, and the $F$ ratio for each independent variable. 


\section{TABLE 5 \\ Oneway ANOVA with \\ Anger as Dependent Variable}

\begin{tabular}{|c|c|c|c|}
\hline $\begin{array}{c}\text { Independent } \\
\text { Variable }\end{array}$ & D.F. & $\begin{array}{c}\text { Mean } \\
\text { Squares }\end{array}$ & F Ratio \\
\hline Sex & 1 & .15 & .14 \\
\hline LD & 1 & 8.55 & $7.78^{\star}$ \\
\hline Ability & 1 & .90 & .80 \\
\hline Effort & 1 & 63.75 & $62.94^{\star \star}$ \\
\hline
\end{tabular}

${ }^{*} \mathrm{p}<.01$

${ }^{* *} \mathrm{p}<.001$

Significant main effects were found for learning disability, $F(1$,

$80)=7.78, \mathrm{p}<.01$, and effort, $F(1,80)=62.94, \mathrm{p}<.001$. Anger was

greatest for students with perceived lower effort. Students who did

not have a learning disability also received a higher rate of anger.

A regression analysis was completed in order to examine the

effects of the independent variables upon the dependent variable.

Table 6 presents the Beta coefficients, T statistic, and the

significance of $\mathrm{T}$.

TABLE 6

Regression with

Anger as Dependent Variable

\begin{tabular}{|c|c|c|c|}
\hline & Beta & $\begin{array}{c}\text { T } \\
\text { Statistic }\end{array}$ & $\begin{array}{c}\text { Signif. Of } \\
\mathbf{T}\end{array}$ \\
\hline Effort & -.299 & -7.975 & $.001^{*}$ \\
\hline Ability & .035 & .948 & .343 \\
\hline Sex & .014 & .395 & .693 \\
\hline LD & -.109 & -2.921 & .003 \\
\hline
\end{tabular}

Note: $\mathrm{R}$ Square $=.1033$

${ }^{*} \mathrm{p}<.001$ 
Both effort and learning disability can be seen as having a significant relationship with the amount of anger that is felt towards a student. The R square shows that approximately $10 \%$ of the variance can be explained from the combination of the independent variables. As can be seen from the tables, the $10 \%$ is made up mostly from effort and learning disability.

\section{PITY}

The third question asked respondents to rate their pity towards the hypothetical students. The answer scale was Likert based with a score of 1 meaning very little pity and a score of 7 meaning very much pity. It was hypothesized that teachers would have a higher rate of pity towards female learning disabled students than male learning disabled students. The mean scores were examined for this question. Table 7 presents the mean scores and standard deviations for the dependent variable pity. 
TABLE 7

Mean Teacher Responses to Pity Question

MALE

\section{HIGH ABILITY}

LOW ABILITY

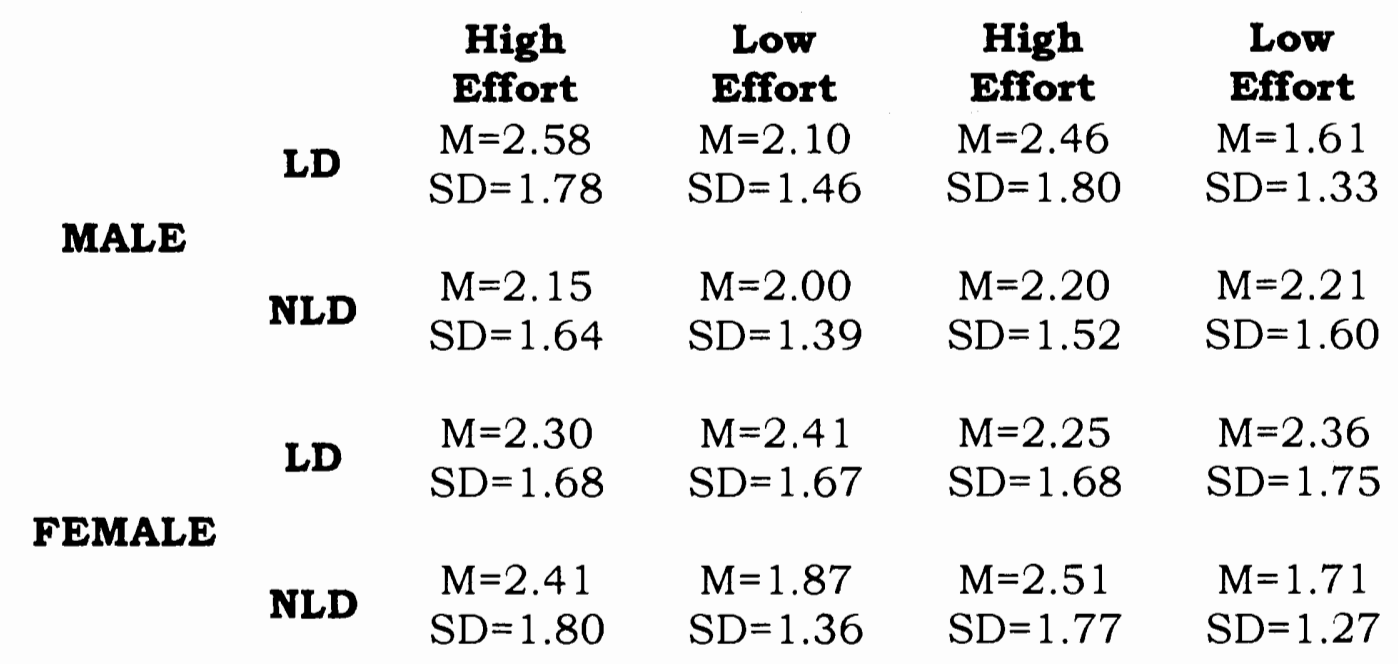

Note. $\mathrm{LD}=$ learning disabilities; $\mathrm{NLD}=$ no learning disabilities. Pity scale: 1 (very little) to 7 (very much).

The two highest mean scores of pity were 2.58 and 2.51 . The student associated with the mean score of 2.58 was a high ability, high effort, learning disabled male. The student associated with the mean score of 2.51 was low ability, high effort, non-disabled female. The respondents exhibited a higher rate of pity for the learning disabled female when the female had lower effort. A higher rate of pity was exhibited for the male learning disabled student when he had higher effort. The opposite was true for the non-disabled female and male students. This is the exact same pattern as was found for 
the variable anger. There could be many theories about why this pattern has repeated itself. For one, it is interesting to note that it occurred with both anger and pity, two of the variables that received many comments from the subjects (this is addressed in more detail in Chapter V). Secondly, it could be theorized that they feel that low effort learning disabled females and non-disabled males should receive more anger and pity for some reason or another. It is difficult to suggest why somebody answers the way they do and what they are thinking, but it appears that there is another variable that is unknown that may help in explaining these scores.

An ANOVA was used to examine whether or not there are any significant differences. Table 8 presents the data from the ANOVA, including the mean sums, degrees of freedom, and the F ratio.

\section{TABLE 8}

Oneway ANOVA with

Pity as Dependent Variable

\begin{tabular}{|c|c|c|c|}
\hline $\begin{array}{c}\text { Independent } \\
\text { Variable }\end{array}$ & $\begin{array}{c}\text { D.F } \\
\cdot\end{array}$ & $\begin{array}{c}\text { Mean } \\
\text { Squares }\end{array}$ & F Ratio \\
\hline Sex & 1 & .689 & .264 \\
\hline LD & 1 & 2.626 & 1.007 \\
\hline Ability & 1 & .564 & .216 \\
\hline Effort & 1 & 16.576 & $6.411^{*}$ \\
\hline${ }^{*} \mathrm{p}<.05$
\end{tabular}


A significant main effect for effort, $F(1,80)=6.411, p<.05$, was found for the rate of pity that exhibited by the subjects. The higher the perceived amount of effort was produced by the student, the more pity the subjects felt towards that student.

A regression analysis was performed to examine the size of the effects that the independent variables had upon the dependent variable. Table 9 presents the Beta coefficients, $T$ statistic, and significance of $\mathrm{T}$.

TABLE 9

Regression with

Pity as Dependent Variable

\begin{tabular}{|c|c|c|c|}
\hline & Beta & $\begin{array}{c}\text { T } \\
\text { Statistic }\end{array}$ & $\begin{array}{c}\text { Signif. Of } \\
\text { T }\end{array}$ \\
\hline Effort & .099 & 2.529 & .011 \\
\hline Ability & .018 & .467 & .641 \\
\hline Sex &. .020 & -.516 & .606 \\
\hline LD & .039 & 1.00 & .314 \\
\hline
\end{tabular}

Note: $\mathrm{R}$ Square $=.0122$

From the regression analysis, it can be concluded that effort does have a relationship with the rate of pity that is given to a hypothetical student. Effort, again shows to be a significant variable with a significance of .011 . The $R$ square is very weak and 
does not show that the combination of the variables helps in explaining the variance in the dependent variable.

\section{EXPECTATIONS FOR FUTURE FAILURE}

The last question asked respondents to predict how likely the hypothetical students will fail on future tests. The answers were scored on a Likert scale with 1 meaning very unlikely for failure on future tests, and 7 meaning very likely for failure on future tests. It was hypothesized that teachers will have higher expectations for future failure by males with learning disabilities specifically, and males in general. The mean scores were examined for this question as well. Table 10 presents the mean scores and standard deviations for the dependent variable fail. 
TABLE 10

Mean Teacher Responses to Expectations for Future Failure Question

HIGH ABILITY

LD

MALE

FEMALE
High

Effort

\section{Low} Effort

$\mathrm{M}=3.09$

$\mathrm{SD}=1.26$

$\mathrm{M}=3.82$
$\mathrm{SD}=1.57$
LD

High

Effort

Low

$\mathrm{M}=3.73$

Effort

$\mathrm{M}=3.92$

$\mathrm{SD}=1.83$

$\mathrm{SD}=2.25$

LOW ABILITY

$$
\begin{array}{cccc}
\mathrm{M}=2.15 & \mathrm{M}=4.48 & \mathrm{M}=3.25 & \mathrm{M}=4.51 \\
\mathrm{SD}=1.32 & \mathrm{SD}=1.26 & \mathrm{SD}=1.58 & \mathrm{SD}=1.34 \\
& & & \\
\mathrm{M}=2.74 & \mathrm{M}=3.73 & \mathrm{M}=3.51 & \mathrm{M}=4.19 \\
\mathrm{SD}=1.61 & \mathrm{SD}=1.64 & \mathrm{SD}=1.98 & \mathrm{SD}=1.91
\end{array}
$$

$$
\text { NLD } \quad M=2.12 \quad M=4.33 \quad M=3.60 \quad M=3.89
$$

$\mathrm{SD}=1.09 \quad \mathrm{SD}=1.91 \quad \mathrm{SD}=1.37 \quad \mathrm{SD}=1.74$

Note. $L D=$ learning disabilities; $N L D=$ no learning disabilities. Expectations for future failure scale: 1 (very unlikely) to 7 (very likely).

Males on the most part were expected to fail more than females. The only time this was different was when a female was of low ability, high effort and non-disabled (mean score was 3.60) when compared to the non-disabled male. When a female was low ability, low effort, and learning disabled, the mean score (4.19) was higher than the male learning disabled counterpart. It is interesting to note that the highest mean score for future failure was for a low ability, low effort, non-disabled male. This was the same type of pattern as was seen for the variable of reward, except this time the 
differences occur when the student is of low ability. It could be theorized that the reason the low ability, low effort, non-disabled male was rated the highest is because teachers might view this type of student as the least successful and hardest to teach. When failure was put with the demographic questions in an ANOVA, the variable of education level did show to be significant, $F(5,79)=$ $2.87, \mathrm{p}<.05$, for the situations of low ability, high effort and low effort, learning disabled students. The amount of education the subjects had could help explain the variance in failure only for these situations. The other situations appear to have some other variable that might help explain the variance in failure.

An ANOVA was used to examine the relation of the independent variables with the dependent variable fail. Table 11 presents the data results from the ANOVA with the mean squares, degrees of freedom, and the F ratio.

TABLE 11

Oneway ANOVA with Fail as Dependent Variable

\begin{tabular}{|c|c|c|c|}
\hline $\begin{array}{c}\text { Independent } \\
\text { Variable }\end{array}$ & D.F & $\begin{array}{c}\text { Mean } \\
\text { Squares }\end{array}$ & F Ratio \\
\hline Sex & 1 & 2.139 & .685 \\
\hline LD & 1 & .351 & .112 \\
\hline Ability & 1 & 43.576 & $14.264^{*}$ \\
\hline Effort & 1 & 188.139 & $66.521^{*}$ \\
\hline${ }^{*} \mathrm{p}<001$ & \multicolumn{3}{|c}{}
\end{tabular}


Significant main effects for ability, $F(1,80)=14.264, p<.001$, and effort, $F(1,80)=66.521, p<.001$, were found for expectancy of future failure. The lower the ability a student was perceived as having, the higher expectations for future failure. This was also the case for perceived effort.

A regression analysis was completed to more thoroughly examine this relationship, and to examine the effects between the other variables. Table 12 presents the regression analysis data showing the Beta coefficient, $\mathrm{T}$ statistic, and the significance of $\mathrm{T}$.

TABLE 12

Regression with

Fail as Dependent Variable

\begin{tabular}{|c|c|c|c|}
\hline & Beta & $\begin{array}{c}\text { T } \\
\text { Statistic }\end{array}$ & $\begin{array}{c}\text { Signif. Of } \\
\text { T }\end{array}$ \\
\hline Effort & -.307 & -8.243 & $.001^{*}$ \\
\hline Ability & -.147 & -3.967 & $.001^{\star}$ \\
\hline Sex & .032 & .879 & .379 \\
\hline LD & .013 & .356 & .721 \\
\hline
\end{tabular}

Note: $\mathrm{R}$ Square $=.1175$

${ }^{*} \mathrm{p}<.001$

According to the regression analysis, ability and effort show the strongest relation to the expectation for failure on future tests. Again, the negative values show the direction of the change in the expectation for failure on future tests. The $\mathrm{R}$ square shows that 
approximately $12 \%$ of the variance in expectancy for future failure can be explained by the combination of the independent variables. According to the table, the majority of the variance is explained by effort and ability.

\section{INTERACTIONS BETWEEN VARIABLES}

When examining the mean responses for each of the dependent variables crossed by the independent variables, it could be seen that a possible interaction was occurring between the various independent variables. In order to examine the interactional effects between the variables, a simple factorial ANOVA was completed for each dependent variable (see appendix $\mathrm{C}$ for complete tables).

For the variable reward, a significant 2 -way interaction between ability and learning disability was found, $F(1,80)=$ $11.128, \mathrm{p}<.005$. This is considered a disordinal interaction because when a student was of high ability and learning disabled, they were rewarded more. On the other hand, when a student was low ability and non-disabled, this type of student was rewarded more.

A significant 3-way interaction between effort, learning disability, and sex was found for the rate of anger given to a 
student, $F(1,80)=7.824, p<.01$. It was found that a low effort, non-disabled, male was given a higher rate of anger than a female, low effort, non-disabled student. A 2-way interaction was also found between effort and learning disability, $F(1,80)=6.873$, $\mathrm{p}<.01$. Generally, a low effort, non-disabled student would receive a higher rate of anger. This can be seen when examining the mean responses for the dependent variable of anger.

A 3-way interaction was found between effort, learning disability, and sex for the amount of pity that was exhibited for each student, $F(1,80)=7.255, \mathrm{p}<.01$. This interaction was again a disordinal interaction. A higher rate of pity was exhibited for a student who had high effort, non-disabled, female; and high effort, learning disabled, male. From the mean responses, it can be seen that effort, learning disability, and sex do make a difference concerning the amount of effort that is exhibited by the subjects.

Expectancy for future failure resulted in several interactional effects between the variables. There were two 2 -way interactions. First, an interaction occurred between ability and effort, $F(1,80)=$ 13.706, $\mathrm{p}<.001$. Second, an interaction occurred between effort and learning disability, $\mathrm{F}(1,80)=11.495, \mathrm{p}<.005$. A 3-way interaction also occurred between ability, effort, and learning disability, F (1, 
$80)=4.386, p<.05$. A subject had higher expectations for future failure by a student who was low effort, low ability, and learning disabled. When the student was non-disabled, it was found that higher expectations for future failure would occur when the student was low effort and high ability.

From examining interactional effects between the different variables, perhaps it will help explain the different responses from the subjects. This will also be discussed in Chapter V more thoroughly.

\section{CONCLUSION}

This chapter discussed the findings for each of the dependent variables. An analysis of variance and regression analysis were completed for each dependent variable and the data was presented. The next chapter will discuss these findings in depth and what the implications are for each hypothesis. There will also be a discussion of the problems with the study, applicability to teachers, and directions for future research. 


\section{CHAPTER V}

\section{DISCUSSION AND CONCLUSION}

\section{INTRODUCTION}

This chapter will discuss the findings in depth for each dependent variable and what the implications are for each hypothesis. A discussion of the problems with this study and directions for future research will be found in the conclusion section of this chapter.

\section{REWARD}

For the dependent variable that measured how much reward (or positive feedback) a teacher would give to a hypothetical student, there were four different hypotheses. The first stated that teachers would attribute reward differently for the female and male students. This was a general statement and could be examined through mean responses. According to the mean responses, teachers did attribute reward differently towards female and male students. If this was examined through statistical tests, like an ANOVA, it would show that the sex of the hypothetical student did not have much bearing on the amount of reward that a teacher would give. The second hypothesis stated that teachers would reward female students with 
learning disabilities more often than male students with learning disabilities. When first examining the mean responses, the female learning disabled students were rewarded more in all scenarios except one. The one scenario where the male with LD was rewarded more than the female was when he and the female with LD were of high ability and low effort. The mean responses do not show whether this is a significant outcome, so an examination of an ANOVA or a regression analysis was performed. According to these tests, the sex of the student is not a significant variable for explaining why a teacher would give a certain amount of reward to a student.

The third hypothesis stated that teachers would reward female students more than male students who are non-disabled. Again the mean responses favored the female students in all occasions except one. The one scenario where a male was rewarded more was when he was of low ability and high effort. According to an ANOVA and a regression analysis, sex was still not a significant variable.

The last hypothesis stated that teachers would attribute reward differently for the hypothetical learning disabled and nondisabled students. The mean responses showed that more reward 
was given to the learning disabled student when they were of high ability. The ANOVA and regression analysis showed that the variable learning disability was not a significant variable for explaining the amount of reward given to a student. Therefore, all of the hypotheses for the dependent variable reward were not supported. An interesting and significant finding was that the independent variable effort was found to be significant from the ANOVA and the regression analysis. This means that the most important variable that can be used to predict how much a teacher will reward or give positive feedback to a student is based on the student's effort.

According to the interactional effects, it was the interaction between ability and learning disability that affected the way the subjects rewarded the hypothetical students. Why would a teacher reward a high ability, low effort learning disabled male more than the female counterpart? It could be due to the idea that teachers want to see this student succeed, and by giving him more positive feedback than the female it could motivate him to try harder. The question is why is there not the same amount of reward for females and males of the same ability and effort if they want to see the students succeed? This might be due to the way teachers view their 
male and female students. Even though they may not admit it, they do treat and see males and females differently within their classrooms. This can also be an explanation for the non-disabled students. It is interesting to note that the male students, both learning disabled and non-disabled, were given more reward than the females. The learning disabled dealt with high ability, low effort; and the non-disabled was low ability, high effort. This finding was probably due to the interaction of the level of ability the student had and whether or not there was a learning disability. Perhaps teachers feel that a learning disabled student with low ability does not have much of a chance to succeed, so there is not any need for reward. Whereas, a low ability, high effort, non-disabled male might have a better chance of succeeding with the extra positive feedback and motivation. There could be other possibilities for the reasoning of the amount of reward given to hypothetical students, but the key point is that the students are hypothetical and may not be representative of real students, so it is difficult to theorize why teachers might answer the way they did. 
ANGER

The dependent variable that measured how angry a teacher would be with a hypothetical student also had four hypotheses. The first stated that teachers would attribute anger differently for female and male students. Again the mean responses showed that there was a difference between the males and females, but from the ANOVA and regression analysis, sex was not a determining variable.

The second hypothesis stated that teachers would exhibit a lower rate of anger for female learning disabled students than their male counterparts. A lower rate of anger was shown for the female learning disabled students when they were considered to have a higher effort, based on the mean responses. Sex was not a significant variable according to the ANOVA and the regression analysis.

The third hypothesis stated that teachers would exhibit a lower rate of anger for female non-disabled students than for their male counterparts. The same finding was true for this hypothesis as was for the second hypothesis.

The fourth hypothesis stated that teachers would attribute anger differently for the learning disabled student and the nondisabled student. According the mean responses there was a 
difference between the learning disabled and non-disabled students. The significant finding is that according to the ANOVA and the regression analysis, the variable learning disability was found to be significant in explaining the amount of anger that a teacher would feel towards a hypothetical student. The variable effort was also found to be significant. Perhaps it is the combination of the amount of effort a student has and whether or not they are learning disabled that will help predict the amount of anger that a teacher feels for their failing students. According to the factorial ANOVA, an interaction does occur between effort and learning disability. Another interaction that was found was between effort, learning disability, and sex. Therefore, the gender of the student can have an impact upon the amount of anger exhibited towards that student when effort and learning disability and also taken into account. Another possible explanation could be due to the subjects' age. It was found that age was significant in explaining the variance in anger. It was found that the older the subject was, the more anger they were portrayed as having. If the variables effort, learning disability, and age all were significant in explaining the changes in anger, why did the means show up the way they did? A possibility could be due the unequal number of surveys or perhaps the order of 
the survey questions. When the subjects had form A, they started with a high ability, high effort, non-disabled female, and they had more anger for her than the subjects who started with the nondisabled male. Also, form A had two more subjects filling it out than did form B. Perhaps this could be the reason for the pattern of the mean responses.

According to the findings, three of the hypotheses were not supported. The last hypothesis, concerned with a difference in rate of anger between the learning disabled and non-disabled students can be supported based upon the results from the ANOVA and the regression analysis.

\section{PITY}

The dependent variable that measured the amount of pity that a teacher would express towards a hypothetical student also had four hypotheses. The first hypothesis stated that teachers would attribute pity differently for female and male students. According to the findings, this was found to be true in the mean responses, but it was not significant enough to support the hypothesis.

The second hypothesis stated that teachers would exhibit a higher rate of pity for female learning disabled students than for 
their male counterparts. A higher rate of pity was exhibited for females (based on mean responses) when they were of low effort. Again, after examining an ANOVA and a regression analysis the sex variable was not a significant finding.

The third hypothesis stated that teachers would exhibit a higher rate of pity for female non-disabled students than for their male counterparts. Mean responses showed this finding only for females who exhibited high effort. Sex has not been shown to be a significant variable, thus the first three hypotheses for the dependent variable of pity cannot be supported.

This is the same pattern as was seen for anger. Again, an explanation might be due to the design of the survey. It might also be due to the fact that the subjects did not care for the words pity or anger. Though, the subjects rated higher on the pity scale than the anger scale overall. Another explanation could again be due to the interaction of several of the variables. Effort, learning disability, and sex were found to have an interactional effect upon the amount of pity that was exhibited. This could also help in the explanation for the last hypothesis.

The last hypothesis stated that teachers would attribute pity differently for learning disabled and non-disabled students. 
According to the findings, this hypothesis was not supported based on the statistical tests that were used. The variable that was found to have significance was effort. Again, this variable appears to help in the prediction or explaining of the amount of pity that a teacher would feel towards a particular student. Combining the perceived amount of effort, whether the student has a learning disability or not, and whether the student is male or female also will help explain the amount of pity that is exhibited.

\section{EXPECTANCY FOR FUTURE FAILURE}

The dependent variable of predicting failure on future tests had four hypotheses. The first hypothesis stated that teachers would attribute future failure differently for females and males. According to the findings, this was found to be true when examining the mean responses, but it was not a significant variable.

The second hypothesis stated that teachers would have higher expectations for future failure by males with learning disabilities than their female counterparts. The mean responses showed this to be true in all cases except when the female learning disabled student had low ability and low effort. According to the ANOVA and the regression analysis, sex was not a significant variable. 
The third hypothesis stated that teachers would have higher expectations for future failure by non-disabled males than for their female counterparts. Again, the mean responses found this to be true in all cases except one. When non-disabled females had high ability and low effort, they were shown to have a higher expectation for future failure than the males were. The ANOVA and regression analysis did not show that sex was a significant variable. Therefore, the first three hypotheses were not supported. The variable that showed to be significant was the amount of effort that was given by the students.

The question of why males had a higher expectancy rate for future failure must be discussed. Is there a reason for males to fail more than females once they have already failed a test? Perhaps this is the reasoning that teachers believe. Maybe it is more difficult to get a male back on track than a female due to outside influences. Males are viewed as being more aggressive, which allows outside forces to influence a male's behavior. Teachers might have higher expectations for females to succeed, since they are seen as passive and as being intimidated. Teachers might also want females to succeed in school today, because it is more acceptable to be an intelligent female. It might also be more acceptable for a male to fail 
than a female, since a male can still receive a higher paying job in the workforce after school.

The fourth hypothesis stated that teachers would attribute future failure differently for the learning disabled and non-disabled students. According to the mean responses, this was found to be true. Generally, the learning disabled students were expected to fail more than non-disabled students. The ANOVA and regression analysis did not show that whether a student of learning disabled or not was a significant variable. Besides effort being significant, the amount of ability was also found to be significant. Therefore, the last hypothesis was not supported. The combination of effort and ability appear to help predict the expectations that a teacher will have for the future failure of their students. This was found to be true from examining the interactions between the variables. Effort and ability was found to have a significant interaction, as well as effort and learning disability. Finally, it was found that the combination of these three variables had a significant interactional effect. Therefore, it is important to examine effort, ability, and learning disability when trying to explain the expectations for future failure by a student. 


\section{CONCLUSION}

It was interesting to find that the variable of sex did not have any significant bearing by itself upon any of the dependent variables, and that the variable of effort was seen to be significant throughout all of the dependent variables. Yet, sex was found to interact with effort and learning disability for anger and pity. The question is why sex was not found as a main effect, because according to the literature concerning gender differences (Brophy $\&$ Good, 1974; Clarizio \& Phipps, 1986; Payette \& Clarizio, 1994;

Phipps, 1982; Shaywitz et al., 1990; Vogel, 1990), there should have been a gender difference found. Sex was not the variable that the subjects used, rather it was the amount of effort that a student had that predicted the different attributes the teacher would have towards that student. Some of the problems this study encountered may help explain why sex was not found to be a significant variable. Though finding that effort was significant for all of the dependent variables is important and does support other research findings (Cooper \& Burger, 1980; Graham, 1990; Graham \& Weiner, 1986; Graham \& Brown, 1988; Rolison \& Medway, 1985; Weiner, 1977), it is also important to understand why sex was not a significant finding for any of the dependent variables. 
The problems with this study were derived from subjects' comments and from other observations while subjects were taking the survey. There were subjects that complained about the survey, that it was too long, and there was not enough information in the vignettes for the subjects to make a judgment call. For example, many subjects wrote comments concerned with other influences that the hypothetical student may be dealing with which would be a distraction to the student and cause failure on a test. One comment was that "more information is needed about the child in the study (what else is happening, it could be my test is bad)". It appeared that subjects would examine the test that was given and either rewrite the test or give the same test over to the student once they discussed with the student what was going on.

"No reason for anger, just try to modify assignments to get some completion and motivate. Find out what the underlying problem is."

"I just would not blame or get angry at a child for failing a test. I think it's a reflection on me as a teacher!"

"If all these students failed the test-either the teacher hasn't taught it well or it's a poor test. Reteach, or other options."

Other comments that the subjects wrote about were concerned with the individual student.

"I marked all these situations the same because it does not matter who or what they do. Everyone is treated the same. 
How a student tests is a matter of choice, life situations (home life), support, and abilities. All I want is every kids best!"

"So much depends on the individual that I find it hard to answer hypothetical questions like these."

"Tests, tests, tests, what about academic work, creativity, personality, types of learners, strengths and weaknesses? I don't believe tests measure all attributes academically."

"All students are treated and regarded as individuals in all aspects of learning. Just like your survey, every child brings their own learning capabilities and desires to class."

The majority of comments dealt with the variables of pity and anger. Some subjects questioned why they would feel pity or anger towards any student. Some comments even suggested better wording for pity and anger. For pity, subjects commented that empathy or concern might be better. For anger, it was suggested that disappointment or concern should be used. A suggestion for why the subjects were concerned with the words of pity and anger could be because they are students and have higher ideals than possibly teachers in the workplace. Comments that can relate to this idea are as follows:

"As we are training to be teachers, anger and pity are choices (we) I would never choose."

"I don't usually feel anger or pity for students. I think you need to be more objective than that."

"Anger and pity, on the teachers part, belong nowhere in the classroom." 
"I don't think pity is a word that applies to any students." According to the subjects' comments, it appears that they focused on the fact that there was not enough information given, and the words pity and anger were too strong of emotions. This might help explain some of the findings or might help to better understand why the subjects answered the way they did.

It is interesting to note that in almost all cases of written factors that helped the subjects make their decisions (question \#5 on survey), the variable effort was stated the most times, followed by ability and learning disability.

Other problems that may have contributed to the hypotheses not being supported is the number of surveys returned. It would have been more helpful to have a larger sample size, and a sample size that was more diverse in the educational field. The survey probably was too long to hand out to students in class, so there might have been feelings to rush through the survey in order to have their class start. Another problem with the design could have been that there were two forms, and there were an unequal number of subjects that completed the surveys. With the number being unequal, it could have made the mean responses larger or smaller based on the extra subjects or lack of subjects. Granted, the 
number of subjects that answered one survey compared to the second survey is menial (42 answered one survey and 38 answered another), it still might help explain why some of the mean responses were larger or smaller based on the sex of the hypothetical student.

Possibly there were other problems with the design of the survey, but the problems were not found beforehand through a pretest. A pre-test would have been useful to find out about the wording of the questions and any other problems.

Another issue concerning this study was the limitations of the subjects. One limitation is the fact that the subjects were only students from one university. If more graduate education programs would have been used, there would have been a better chance of getting a more representative sample. It is difficult to say how representative PSU is compared to other universities, but by only examining one institution it lessons the ability to generalize to other graduate education students.

Another limitation is the fact that the subjects were students. There is probably a difference in the responses between students and teachers. There should have been a question concerning whether or not their teaching experience was due to student teaching or rather due to being an experienced teacher. An 
experienced teacher would probably view these hypothetical students and respond to them differently than would a student teacher. Examining this difference would be interesting for future research.

\section{APPLICABILITY TO TEACHERS}

It is important to discuss the implications this study has to teachers and how they might use this information for their benefit. Teachers can use the information from this study by applying the results to their own interactions and ways of dealing with their students who fail a test. An important finding that teachers could use is that many of them will rely upon the perceived amount of effort that a student is portraying in order to determine the teachers' reaction toward that student. It is as equally as important to emphasize that gender could possibly have an interactional effect with effort, therefore it is not only effort that teachers are looking for but rather the combination of gender and effort. Besides this one interaction, there were other interactions that occurred and it is important to realize that it is not only one variable that explains a behavior, rather it can be the interactions between several variables. This study would allow teachers the knowledge that they need to be 
aware of their expectations and interactions they have concerning their students.

\section{DIRECTIONS FOR FUTURE RESEARCH}

The possibilities for future research on this subject are numerous. For one, it would be interesting to test both students in education and teachers in public schools and compare them to see if there are any differences. Another research possibility is to add the variable of race into the factor to find if there are differences between learning disabled and non-disabled students who differ in race. Payette and Clarizio (1994) discuss that $21.6 \%$ of secondary school youth in special education are African-American, whereas only $12 \%$ of secondary age youth in general are African-American. This suggests that race is a biasing factor in the special education placement. It would be interesting to examine race as a variable in a study that looks at attributional tendencies of teachers towards their students. This would help in understanding whether or not there is a racial bias in teachers and could allow for teachers to change their outlook of their students.

This study was unable to support the hypotheses concerned with a gender bias, but it did allow some insight into what teachers 
do look at when they see a student of theirs fail. That seems to be the amount of effort the student exhibits. This study has lent itself to some interesting findings, but more importantly it expanded the knowledge of attributional tendencies of teachers towards their failing students. Obviously, there is more to be learned on this subject and the study design can be improved upon. Overall, it is an interesting subject with many different variables to be examined and with many different explanations. 


\section{References}

Bar-Tal, D., \& Darom, E. (1979). Pupils' attributions of success and failure. Child Development, 50, 264-267.

Bergan, J., \& Smith, J. (1966). Effects of socioeconomic status and sex on prospective teachers' judgments. Mental Retardation, 4, 13-15.

Brophy, J. (1981). Teacher praise: A functional analysis. Review of Educational Research, 51, 5-32.

Brophy, J., \& Good, T. (1974). Teacher-student relationships: Causes and consequences. New York: Holt, Rinehart, \& Winston.

Caplan, P. (1977). Sex, age, behavior, and school subject as determinants of report of learning problems. Journal of Learning Disabilities, 10, 314-320.

Clarizio, H.F., \& Phillips, S.E. (1986). Sex bias in the diagnosis of learning disabled students. Psychology in the Schools,23(1), 44-52.

Clark, M. (1997). Teacher response to learning disability: A test of attributional principles. Journal of Learning Disabilities, 30, 1, 69-79.

Cooper, H.M., \& Burger, J.M. (1980). How teachers explain students' academic performances: A categorization of free response academic attributions. American Educational Research Journal, 17, 95-109.

Cooper, H.M. \& Good, T.L. (1983). Pygmalion grows up. New York: Longman.

Feshbach, N. (1969). Student teacher preferences for elementary school pupils varying in personality characteristics. Journal of Educational Psychology, 60, 126-132. 
Finucci, J.M., \& Childs, B. (1981). Are there really more dyslexic boys than girls? In Ansara, A., Geshwind, N., Galaburda, A., Albert,M., \& Gartrell, N. (Eds.), Gender Differences in Dyslexia, Towson, MD: Orton Dyslexia Society; 1-9.

Gillung, T., \& Rucker, C. (1977). Labels and teacher expectations. Exceptional Children, 43, 464-465.

Graham, S. (1984). Communicating sympathy and anger to black and white children: The cognitive (attributional) consequences of affective cues. Journal of Personality and Social Psychology, 47, 40- 54.

Graham, S. (1990). On communicating low ability in the classroom: Bad things good teachers sometimes do. In S. Graham \& V. Folkes (Eds), Attribution theory: Applications to achievement, mental health, and interpersonal conflict (pp.1736). Hillsdale, NJ: Erlbaum.

Graham, S., \& Brown, J. (1988). Attributional mediators of expectancy, evaluation, and affect: A response time analysis. Journal of Personality and Social Psychology, 55, 873-881.

Gregory, M. (1977). Sex bias in school referrals. Journal of School Psychology, 15, 5-8.

Hallahan, D., Kauffman, J., \& Lloyd, J. (1996). Introduction to Learning Disabilities. Allyn and Bacon.

Harris, M., Milich, R., Corbitt, E., Hoover, D., \& Brady, M. (1992). Self-fulfilling effects of stigmatizing information on children's social interactions. Journal of Personality and Social Psychology, 63, 1, 41-50.

Harvey, J., Ickes, W., \& Kidd, R. (1978). New Direction in Attribution Research: Vol. 2. Hillsdale, NJ: Erlbaum.

Heider, F. (1958). The Psychology of Interpersonal Relations. New York: Wiley. 
Jones, E. \& Davis, K. (1965). From acts to dispositions: The attribution process in person perception. In L. Berkowitz (Ed.), Advances in experimental social psychology (Vol. 2, pp. 219-266). New York: Academic Press.

Jussim, L. (1989). Teacher expectations: Self-fulfilling prophecies, perceptual biases, and accuracy. Journal of Personality and Social Psychology, 57, 3, 469-480.

Kelley, H. (1972). Attribution in social interaction. In E. Jones, D. Kanouse, H. Kelley, R. Nisbett, S. Valins, \& B. Weiner, Attribution: Perceiving the causes of behavior (pp. 1-26). Morristown, NJ: General Learning Press.

Kistner, J.A., Osborne, M., \& Le Verrier, L. (1988). Causal attributions of learning disabled children: Developmental patterns and relation to academic progress. Journal of Educational Psychology, 80,82-89.

Leinhardt, G., Seewald, A., \& Zigmond, N. (1982). Sex and race differences in learning disabilities classrooms. Journal of Educational psychology, 74, 835-845.

Lengermann, P. \& Niebrugge, J. (1996). Contemporary feminist theory. In G. Ritzer, Modern sociological theory (pp. 299-350). The McGraw-Hill Companies, Inc.

Maccoby, E., \& Jacklin, C. (1974). The Psychology of Sex Differences. New York: Praeger.

McIntosh, R., Vaughn, S., Schumm, J., Haager, D., \& Lee, O. (1993). Observations of students with learning disabilities in general education classrooms. Exceptional Children, 60, 3, 249-261.

Mercer, C. (1991). Students With Learning Disabilities. Macmillan Publishing Company.

Palmer, D. (1983). An attributional perspective on labeling. Exceptional Children, 49, 5, 423-429. 
Payette, K.A., \& Clarizio, H.F. (1995). Discrepant team decisions: The effects of race, gender, achievement and IQ on LD eligibility. Psychology in the Schools, 31,40-48.

Phipps, P. (1982). The LD learner is often a boy-why? Academic Therapy, 17, 425-430.

Restivo, S. (1991). The Sociological Worldview. Basil Blackwell, Inc.

Rolison, M. \& Medway, F. (1985). Teachers' expectations and attributions for student achievement: Effects of label, performance pattern, and special education intervention. American Educational Research Journal, 22, 4, 561-573.

Ryckman, D. (1981). Sex differences in a sample of learning disabled children. Learning Disability Quarterly, 4, 48-52.

Shaywitz, S.E., Shaywitz, B.A., Fletcher, J.M., \& Escobar, M.D. (1990). Prevalence of reading disability in boys and girls: Results of the Connecticut Longitudinal Study. Journal of the American Medical Association, 264(8),998-1002.

Stoller, L., Algozzine, B., \& Ysseldyke, J. (1981). Expectations and attributions for a handicapped child: Teachers pay attention to classroom performance. Educational Research Quarterly, 6, 2, 53-59.

Taylor, M. (1979). Race, sex, and the expression of the self-fulfilling prophesy in a laboratory teaching situation. Journal of Personality and Social Psychology, 37, 897-912.

Tollefson, N., Melvin, J., \& Thippavajjala, C. (1990). Teachers' attributions for students' low achievement: A validation of Cooper and Good's attributional categories. Psychology in the Schools, 27,75-83.

Tollefson, N., Rodriguez, R., \& Franz, C. (1987). Educators' attributions for students' grades. Psychological Reports, 60, 1123-1129.

U.S. Department of Education (1994). Sixteenth Annual Report to Congress on the Implementation of the Individuals with 
Disabilities Education Act. Washington, DC: Author.

Vogel, S. (1990). Gender differences in intelligence, language, visual-motor abilities, and academic achievement in students with learning disabilities: A review of the literature. Journal of Learning Disabilities, 23, 1, 44-52.

Weiner, B. (1977). An attributional approach for educational psychology. In L. Shulman (ed.), Review of Research in Education (Vol. 4). Itasca, IL: Peacock.

Weiner, B. (1990). Searching for the roots of applied attribution theory. In S. Graham \& V. Folkes (Eds.), Attribution theory: Applications to achievement, mental health, and interpersonal conflict (pp. 17-36). Hillsdale, NJ: Erlbaum.

Weiner, B., Frieze, I., Kukla, A., Reed, L., Rest, S., Rosenbaum, R. (1972). Perceiving the causes of success and failure. In $E$. Jones, D., Kanouse, H. Kelley, R. Nisbett, S. Valins, \& B. Weiner, Attribution: Perceiving the causes of behavior (pp. 95120). Morristown, NJ: General Learning Press.

Weiner, B., Russell, D., Lerman, D. (1978). Affective consequences of causal ascriptions. In J. Harvey, W. Ickes, \& R. Kidd, New directions in attribution research (Vol. 2, pp. 59-90). Hillsdale, NJ: Erlbaum. 


\section{APPENDIX A:}

\section{SURVEY}

Thomas is a student in your class. He is a very bright child-among the brightest in the class. He always works hard in class, finishes his assignments, and does his homework properly. He is able to work independently and rarely has to ask for help. He has just failed your most recent test.

1. What feedback would you give this child?

$\begin{array}{ccccccc}1 & 2 & 3 & 4 & 5 & 6 & 7 \\ \text { (negative feedback) } & & & & & \text { (positive feedback) }\end{array}$

2. Rate your anger towards this student.

$\begin{array}{rrrrrrr}1 & 2 & 3 & 4 & 5 & 6 & \begin{array}{c}7 \\ \text { (very much) }\end{array}\end{array}$

3. Rate your pity towards this student.

$\begin{array}{rlllllc}1 & 2 & 3 & 4 & 5 & 6 & \begin{array}{c}7 \\ \text { (very much) }\end{array}\end{array}$

4. Predict how likely it is that this student will fail on future tests
(very unlikely)
(very likely)

$\begin{array}{lllllll}1 & 2 & 3 & 4 & 5 & 6 & 7\end{array}$

5. What factor(s) helped make your decisions for the above questions? 
Rebecca is a student in your class. She is of higher ability than many in her class but has difficulty with tasks she must do in writing, such as writing stories, where she must formulate correct sentences and spell correctly. She receives Resource Specialist Program services which are helping her develop strategies to improve her written work. She works hard but slowly in class, using the methods she was taught; she usually completes assignments. Her work is generally done properly, as well. She has just failed your most recent test.

1. What feedback would you give this child?

$$
\begin{array}{ccccccc}
1 & 2 & 3 & 4 & 5 & 6 & 7 \\
\text { (negative feedback) } & & & & & \text { (positive feedback) }
\end{array}
$$

2. Rate your anger towards this student.

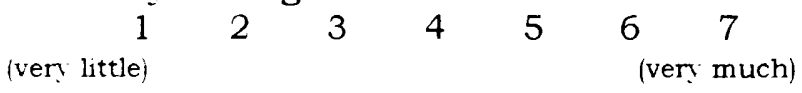

3. Rate your pity towards this student.

$\begin{array}{ccccccc}1 & 2 & 3 & 4 & 5 & 6 & 7 \\ \text { (ver little) } & & & & & & \text { (very much) }\end{array}$

4. Predict how likely it is that this student will fail on future tests

$\begin{array}{lllll}\text { (very unlikely) } & & 4 & 5 & 6\end{array}$

5. What factor(s) helped make your decisions for the above questions? 
Ashley is a student in your class. She has greater aptitude for academic tasks than most children in her class. Although she occasionally does excellent work, she is usually off task and does not participate in class often. She rarely completes class assignments and does not do much of her homework. She has just failed your most recent test.

1. What feedback would you give this child?

$$
\begin{array}{ccccccc}
1 & 2 & 3 & 4 & 5 & 6 & \begin{array}{c}
7 \\
\text { (positive feedback) }
\end{array}
\end{array}
$$

2. Rate your anger towards this student.

$$
\text { (very little) (very much) }
$$

3. Rate your pity towards this student.

$$
\begin{array}{cccccc}
1 & 2 & 3 & 4 & 5 & 6 \\
\text { (very little) } & & & & &
\end{array}
$$

4. Predict how likely it is that this student will fail on future tests

$$
\begin{array}{ccccccc}
1 & 2 & 3 & 4 & 5 & 6 & 7 \\
\text { (very likely) }
\end{array}
$$

5. What factor(s) helped make your decisions for the above questions? 
Jimmy is a student in your class. He is a rather bright boy but has some difficulty with comprehension, both in math and in reading. He sees the resource specialist for assistance with his comprehension difficulties; He does the majority of his class work quickly, often making many errors. Homework is done the same way unless a parent supervises him. His participation in group work varies but is usually limited. He has just failed your most recent test.

1. What feedback would you give this child?

$\begin{array}{ccccccc}1 & 2 & 3 & 4 & 5 & 6 \begin{array}{c}7 \\ \text { (positive feedback) }\end{array}\end{array}$

(negative feedback)

(positive feedback)

2. Rate your anger towards this student.

$\begin{array}{rrrrrr}1 & 2 & 3 & 4 & 5 & 6 \begin{array}{c}7 \\ \text { (very little) }\end{array} \\ & & & & \end{array}$

3. Rate your pity towards this student.

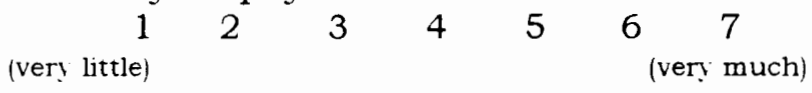

4. Predict how likely it is that this student will fail on future tests

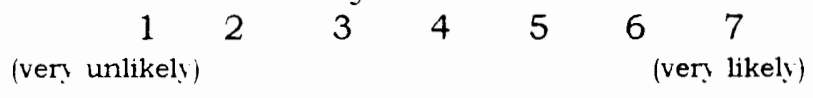

5. What factor(s) helped make your decisions for the above questions? 
Christopher is a student in your class. He has the ability somewhat below that of most children in his class. He works hard in class, asking help when he needs it. He tries to participate in group work. His homework is finished regularly, and class work, even if not always quite finished, is done properly. He has just failed your most recent test.

1. What feedback would you give this child?

$$
\begin{array}{lllllll}
1 & 2 & 3 & 4 & 5 & 6 & 7
\end{array}
$$

(negative feedback) (positive feedback)

2. Rate your anger towards this student.

$\begin{array}{ccccccc}1 & 2 & 3 & 4 & 5 & 6 & 7 \\ \text { (very much) }\end{array}$

3. Rate your pity towards this student.

4. Predict how likely it is that this student will fail on future tests

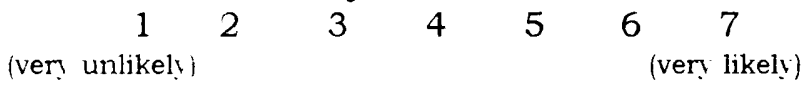

5. What factor(s) helped make your decisions for the above questions? 
Krista is a student in your class. She is considered to have lower aptitude for academic tasks than most children in the class. She works slowly, but hard, in class, generally finishing shortened class assignments. Her family works with her at home, where she finishes her homework and prepares for school. To help her be successful in language arts and math, she receives services from the resource specialist. She has just failed your most recent test.

1. What feedback would you give this child?

(negative feedback)

$\begin{array}{lllllll}1 & 2 & 3 & 4 & 5 & 6 & 7\end{array}$

2. Rate your anger towards this student.

(very little)

$\begin{array}{lllll}3 & 4 & 5 & 6 & 7\end{array}$

(very much)

3. Rate your pity towards this student.
1
34
56
7
(ver. much)

(verr little)

4. Predict how likely it is that this student will fail on future tests

(very unlikely)
12
45
$\begin{array}{ll}6 & 7\end{array}$
(very likely)

5. What factor(s) helped make your decisions for the above questions? 
Amy is a student whose limited ability is below that of most children in her class. She seldom does class work completely, or she hurries through it, making many error. She rarely does her homework or studies at home but always has an excuse why she hasn't. When encouraged to slow down and work carefully, her work can be appropriate for her grade level. She has just failed your most recent test.

1. What feedback would you give this child?

$$
\begin{array}{ccccccc}
1 & 2 & 3 & 4 & 5 & 6 & 7 \\
\text { (negative feedback) } & & & & & \text { (positive feedback) }
\end{array}
$$

2. Rate your anger towards this student.

$$
\text { (ver little) (very much) }
$$

3. Rate your pity towards this student.

$\begin{array}{rrrrrr}1 & 2 & 3 & 4 & 5 & 6 \begin{array}{c}7 \\ \text { (very little) }\end{array} \\ & & & & & \text { (very much) }\end{array}$

4. Predict how likely it is that this student will fail on future tests $\begin{array}{llllll}1 & 2 & 3 & 4 & 5 & 6 \\ \text { (ver: unlikely) } & & & & & \text { (very likely) }\end{array}$

5. What factor(s) helped make your decisions for the above questions? 
Brian is a student in your class. He is of limited ability as compared to most of his classmates. He seldom completes his class work or homework, is often off task, and does not participate in instructional groups. Because of his deficits in language arts and math, he receives services from the Resource Specialist Program. He has just failed your most recent test.

1. What feedback would you give this child?

(negative feedback)

$$
\begin{array}{lllll}
3 & 4 & 5 & 6 & 7 \\
& & &
\end{array}
$$

2. Rate your anger towards this student.

(very little)

$$
\begin{array}{llllll}
2 & 3 & 4 & 5 & 6 & 7 \\
\text { (very much) }
\end{array}
$$

3. Rate your pity towards this student.

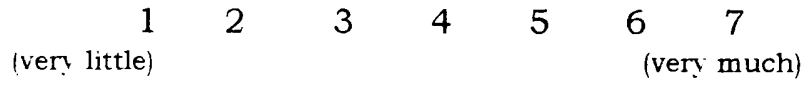

4. Predict how likely it is that this student will fail on future tests
(vern unlikely)
$6 \quad 7$
(very likely)

5. What factor(s) helped make your decisions for the above questions?

\section{Demographic questions}

1. Age:

2. Sex: Male Female (circle one)

3. Education Level:

4. Do you have any teaching experience? Yes No

If yes, what age level do you teach? Elementary Middle High

How long have you taught?

5. Comments: 
APPENDIX B:

Statement of Informed Consent

$\mathrm{I}$, , agree to take part in this

research project. I understand that the study involves filling out a survey which requires reading 8 vignettes and answering 5 questions following each vignette and will take approximately 15 minutes. I may not receive any direct benefit from taking part in this study; however, the study may help to increase knowledge that may help others in the future. Polly Chalette has offered to answer any questions I have about the study and what I am expected to do. She has promised that all information given will be kept confidential to the extent permitted by law, and that the names of all people in the study will be kept confidential. I understand that I do not have to take part in this study and may withdraw from this study at any time, and that this will not affect my course grade or my relationship with Portland State University.

I have read and understand the above information and agree to take part in this study.

Date:

Signature:

If you have any concerns or questions about this study, please contact the Chair of the Human Subjects Research Review Committee, Research and Sponsored

Projects, 105 Neuberger Hall, Portland State University, (503)725-3417. 


\section{APPENDIX C:}

FACTORIAL ANALYSIS OF VARIANCE

\begin{tabular}{|c|c|c|c|}
\hline \multicolumn{4}{|c|}{$\begin{array}{l}\text { ANOVA With Reward } \\
\text { As Dependent Variable }\end{array}$} \\
\hline Source of Variation & D.F. & Mean Squares & F Ratio \\
\hline Main Effects & 4 & 25.494 & $11.437^{\star}$ \\
\hline Ability & 1 & 5.625 & 2.523 \\
\hline Effort & 1 & 90.000 & $40.373^{*}$ \\
\hline LD & 1 & 3.600 & 1.615 \\
\hline Sex & 1 & 2.756 & 1.236 \\
\hline 2-way Interactions & 6 & 4.501 & 2.019 \\
\hline Ability x Effort & 1 & 1.056 & .474 \\
\hline Ability x LD & 1 & 24.806 & $11.128^{\star \star}$ \\
\hline Ability x Sex & 1 & .400 & .179 \\
\hline Effort $\times$ LD & 1 & .125 & .056 \\
\hline Effort $\times$ Sex & 1 & .463 & .207 \\
\hline LD x Sex & 1 & .156 & .070 \\
\hline 3-way Interactions & 4 & 1.720 & .771 \\
\hline Ability $x$ Effort $\times$ LD & 1 & 1.261 & .566 \\
\hline Ability $x$ Effort $x$ Sex & 1 & 2.647 & 1.188 \\
\hline Ability x LD x Sex & 1 & 2.336 & 1.048 \\
\hline Effort X LD x Sex & 1 & .635 & .285 \\
\hline 4-way Interactions & 1 & .535 & .240 \\
\hline $\begin{array}{l}\text { Ability x Effort } \times \text { LD } \times \text { Sex } \\
{ }^{*} p<.001 \\
{ }^{* \star} \mathrm{p}<.005\end{array}$ & 1 & .535 & .240 \\
\hline
\end{tabular}




\section{ANOVA With Anger As Dependent Variable}

\begin{tabular}{|c|c|c|c|}
\hline Source of Variation & D.F. & Mean Squares & F Ratio \\
\hline Main Effects & 4 & 18.342 & $18.652^{*}$ \\
\hline Ability & 1 & .900 & .915 \\
\hline Effort & 1 & 63.756 & $64.833^{*}$ \\
\hline LD & 1 & 8.556 & $8.701^{\star *}$ \\
\hline Sex & 1 & .156 & .159 \\
\hline 2-way Interactions & 6 & 1.806 & 1.837 \\
\hline Ability $x$ Effort & 1 & .100 & .102 \\
\hline Ability x LD & 1 & 3.025 & 3.076 \\
\hline Ability x Sex & 1 & .400 & .407 \\
\hline Effort x LD & 1 & 6.759 & $6.873^{\star \star}$ \\
\hline Effort $x$ Sex & 1 & .104 & .106 \\
\hline LD x Sex & 1 & .449 & .457 \\
\hline 3-way Interactions & 4 & 2.788 & $2.835^{\star \star \star}$ \\
\hline Ability $\times$ Effort $\times$ LD & 1 & 2.972 & 3.022 \\
\hline Ability $x$ Effort $\times$ Sex & 1 & .074 & .076 \\
\hline Ability x LD x Sex & 1 & .410 & .417 \\
\hline Effort X LD x Sex & 1 & 7.694 & $7.824^{\star \star}$ \\
\hline 4-way Interactions & 1 & .946 & .962 \\
\hline $\begin{array}{l}\text { bility } x \text { Effort } \times \text { LD x Sex } \\
p<.001 \\
{ }^{*} p<.01 \\
\star^{\star *} p<.05\end{array}$ & 1 & .946 & .962 \\
\hline
\end{tabular}




\section{ANOVA With Pity As Dependent Variable}

\begin{tabular}{|c|c|c|c|}
\hline Source of Variation & D.F. & Mean Squares & F Ratio \\
\hline Main Effects & 4 & 5.114 & 1.971 \\
\hline Ability & 1 & .564 & .217 \\
\hline Effort & 1 & 16.577 & $6.389 *$ \\
\hline LD & 1 & 2.627 & 1.012 \\
\hline Sex & 1 & .689 & .266 \\
\hline 2-way Interactions & 6 & .720 & .278 \\
\hline Ability $\mathrm{x}$ Effort & 1 & .452 & .174 \\
\hline Ability x LD & 1 & 2.139 & .824 \\
\hline Ability $x$ Sex & 1 & .077 & .030 \\
\hline Effort x LD & 1 & .328 & .126 \\
\hline Effort $x$ Sex & 1 & .305 & .118 \\
\hline LD x Sex & 1 & 1.023 & .394 \\
\hline 3-way Interactions & 4 & 5.193 & 2.001 \\
\hline Ability $x$ Effort $\times$ LD & 1 & .195 & .075 \\
\hline Ability x Effort $\mathrm{x}$ Sex & 1 & .007 & .003 \\
\hline Ability x LD x Sex & 1 & 1.747 & .673 \\
\hline Effort X LD x Sex & 1 & 18.824 & $7.255^{\star \star}$ \\
\hline 4-way Interactions & 1 & 1.549 & .597 \\
\hline $\begin{array}{l}\text { bility x Effort x LD x Sex } \\
p<.05 \\
{ }^{*} p<.01\end{array}$ & 1 & 1.549 & .597 \\
\hline
\end{tabular}


ANOVA With Fail As Dependent Variable

\begin{tabular}{|c|c|c|c|}
\hline Source of Variation & D.F. & Mean Squares & F Ratio \\
\hline Main Effects & 4 & 58.552 & $21.940^{\star}$ \\
\hline Ability & 1 & 43.577 & $16.329 \star$ \\
\hline Effort & 1 & 188.139 & $70.500^{\star}$ \\
\hline LD & 1 & .352 & .132 \\
\hline Sex & 1 & 2.139 & .802 \\
\hline 2-way Interactions & 6 & 11.372 & $4.261^{\star}$ \\
\hline Ability x Effort & 1 & 36.577 & $13.706^{\star}$ \\
\hline Ability x LD & 1 & .127 & .047 \\
\hline Ability x Sex & 1 & .564 & .211 \\
\hline Effort x LD & 1 & 30.677 & $11.495^{\star \star}$ \\
\hline Effort $x$ Sex & 1 & .280 & .105 \\
\hline LD x Sex & 1 & .008 & .003 \\
\hline 3-way Interactions & 4 & 5.500 & 2.061 \\
\hline Ability $x$ Effort $x$ LD & 1 & 11.705 & $4.386^{\star \star \star}$ \\
\hline Ability $\mathrm{x}$ Effort $\mathrm{x}$ Sex & 1 & .960 & .360 \\
\hline Ability x LD x Sex & 1 & .815 & .305 \\
\hline Effort X LD x Sex & 1 & 8.521 & 3.193 \\
\hline 4-way Interactions & 1 & 2.867 & 1.074 \\
\hline $\begin{array}{l}\text { bility } x \text { Effort } \times \text { LD x Sex } \\
p<.001 \\
{ }_{k * *}<<.005 \\
p<.05\end{array}$ & 1 & 2.867 & 1.074 \\
\hline
\end{tabular}

